\title{
2. LATE MIOCENE (CN9B SUBZONE) TO HOLOCENE CALCAREOUS NANNOFOSSILS FROM THE WESTERN AND NORTHWESTERN PACIFIC OCEAN, LEG $125^{1}$
}

\author{
Giuliano Ciampo ${ }^{2}$
}

\begin{abstract}
During Leg 125 of the Ocean Drilling Program, nine sites were drilled in the Mariana and Izu-Bonin areas. The sediments recovered range in age from early Pliocene to late Pleistocene in the Mariana Region and from middle Eocene to late Pleistocene in the Izu-Bonin region. This contribution concerns the biostratigraphic study of the latest Miocene (CN9b Subzone) to late Pleistocene interval. A quantitative analysis of all calcareous nannofossil associations was conducted for the interval encompassing late Miocene to the top of the early Pliocene. Moreover, the genera Discoaster, Amaurolithus, and Ceratolithus were quantitatively investigated from the late Miocene to late Pliocene interval. Some bioevents were identified, and variations in the composition of assemblages were linked to climatic changes.
\end{abstract}

\section{INTRODUCTION}

During Leg 125 (February-April 1989), scientists drilled at nine sites in the Mariana and Izu-Bonin areas of the western Pacific (Fig. 1). In the Mariana area, four sites (778-781) are located on the top and flanks of a serpentine seamount (Conical Seamount) in the forearc region. In the Izu-Bonin, area two sites (783-784) are located on the Torishima Forearc Seamount in the forearc basin and three others $(782,785$, and 786 ) along the eastern edge of the forearc basin.

The recovered sediments range in age from middle Eocene (Sites 782 and 786) to Holocene. Uppermost Miocene (CN9b Subzone) to Holocene calcareous nannofossils are discussed.

\section{METHODS}

As a base for biostratigraphy the standard zonation of Okada and Bukry (1980) was used. Light-microscope techniques for studying coccoliths from smear slides also were used. Scanning electron microscope (SEM) was mainly used to determine the first occurrence of Emiliania huxleyi in the late Pleistocene sediments.

Quantitative analysis of the assemblages in the late Miocene-early Pliocene interval (CN9b-CN11b Subzones) was performed. A minimum of 500 specimens was counted for each sample. Furthermore, at least 300 specimens of the genus Discoaster for each sample were counted from the late Miocene to the extinction of the genus in the late Pliocene (CN12d Subzone). The number of specimens in the Ceratoliths group counted in the same time interval depends on the number of discoasters $(n=300)$. The quantitative analysis points out further events for a fine biostratigraphic resolution; the paleoclimatic implications will be commented upon briefly.

In accordance with Backman and Shackleton (1983), Sphenolithus abies and $S$. neobies are considered together in the count; Discoaster variabilis is considered together with $D$. challengeri and D. decorus. Rare Discoaster challengeri is scattered; Discoaster decorus has its first occurrence at the base of the CN11b Subzone and is always very rare.

\footnotetext{
'Fryer, P., Pearce, J. A., Stokking, L. B., et al., 1992. Proc. ODP, Sci. Results, 125: College Station, TX (Ocean Drilling Program).

${ }^{2}$ Dipartimento Scienze della Terra, Università di Napoli, Italy.
}

\section{SITE SUMMARIES}

\section{Mariana Region (Fig. 2)}

In this area, Sites 778 to 781 were drilled on the top or on the flanks of the serpentine Conical Seamount.

Site $778 \quad 19^{\circ} 29.93^{\prime} \mathrm{N}, 146^{\circ} 39.93{ }^{\prime} \mathrm{E}$; water depth, $3917.7 \mathrm{mbsl}$

Site $77919^{\circ} 30.75^{\prime} \mathrm{N}, 146^{\circ} 41.75^{\prime} \mathrm{E}$; water depth, $3947.2 \mathrm{mbsl}$

Site $780 \quad 19^{\circ} 32.5^{\prime} \mathrm{N}, 146^{\circ} 39.2^{\prime} \mathrm{E}$; water depth, $3090 \mathrm{mbsl}$

Only a few scattered samples, in the higher part of the seven holes drilled, provided usually poor and poorly preserved nannofossil assemblages of Pleistocene age (CN14-15 Zones).

No range charts have been provided for these sites.

Site $781 \quad 19^{\circ} 37.91^{\prime} \mathrm{N}, 146^{\circ} 32.56^{\prime} \mathrm{E}$; water depth, $4420.6 \mathrm{mbsl}$

This site is located on a flank of Conical Seamount. Severe etching and reworking affect the nannofossil assemblages because of the great depth and turbiditic sequences. Moreover, several cores and sections are missing because recovery was poor.

Samples from the bottom of the hole contain mixed early/late Pliocene associations, with Ceratolithus armatus, C. cristatus, Discoaster asymmetricus, D. tamalis, Pseudoemiliania lacunosa, Reticulofenestra pseudoumbilicus, and Sphenolithus spp.

Samples 125-781A-26R-1, 17-18 cm, to 125-781A-15R-CC, below a massive basalt (lithologic Unit IB, 72.32-91.80 mbsf) are from early Pliocene (CN11b Subzone), if Reticulofenestra pseudoumbilicus and Sphenolithus, spp. were not reworked, to late Pliocene (CN12a Subzone) in age. Nannofossils are abundant and well preserved, and sometimes discoasters are predominant in these assemblages (Table 1).

Samples above the massive basalt are Pleistocene in age, CN14a Subzone, based on the occurrence of Gephyrocapsa oceanica. Reworking is common, and it was impossible to recognize some extinction events (such as Calcidiscus macintyrei or Helicosphaera sellii) within the early and middle Pleistocene interval (Gartner, 1977); however, the first occurrence of Emiliania huxleyi is at the bottom of Core 125-781A-1R; Cores $125-781 \mathrm{~A}-2 \mathrm{R}$ and $125-781 \mathrm{~A}-3 \mathrm{R}$ were not recovered. The late Pliocene to early Pliocene age indicated in Fig. 21 (p. 195 of the Initial Reports volume for Leg 125; Pearce, Fryer, et al., 1990) for the post-basalt interval must be corrected to Pleistocene. 
A

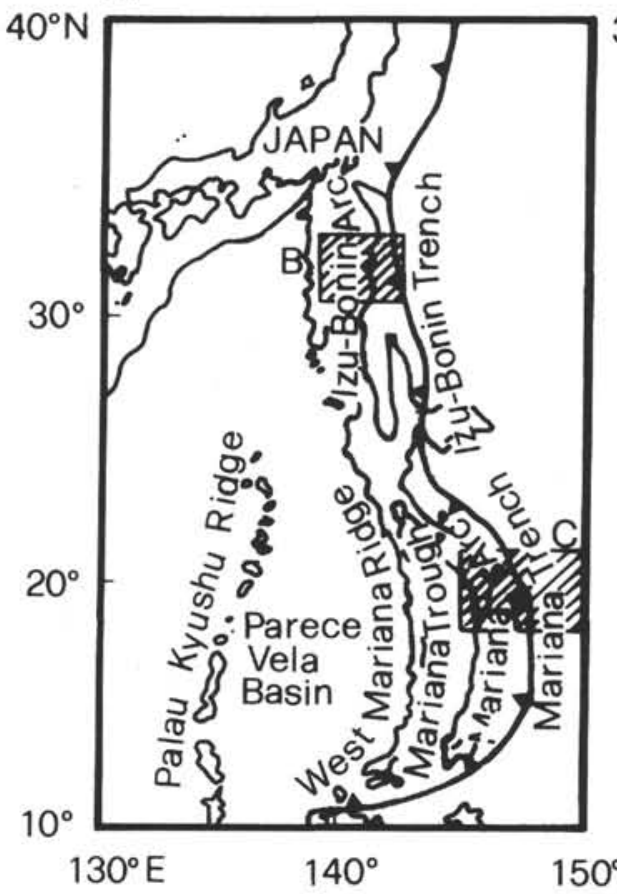

$\mathrm{B}$

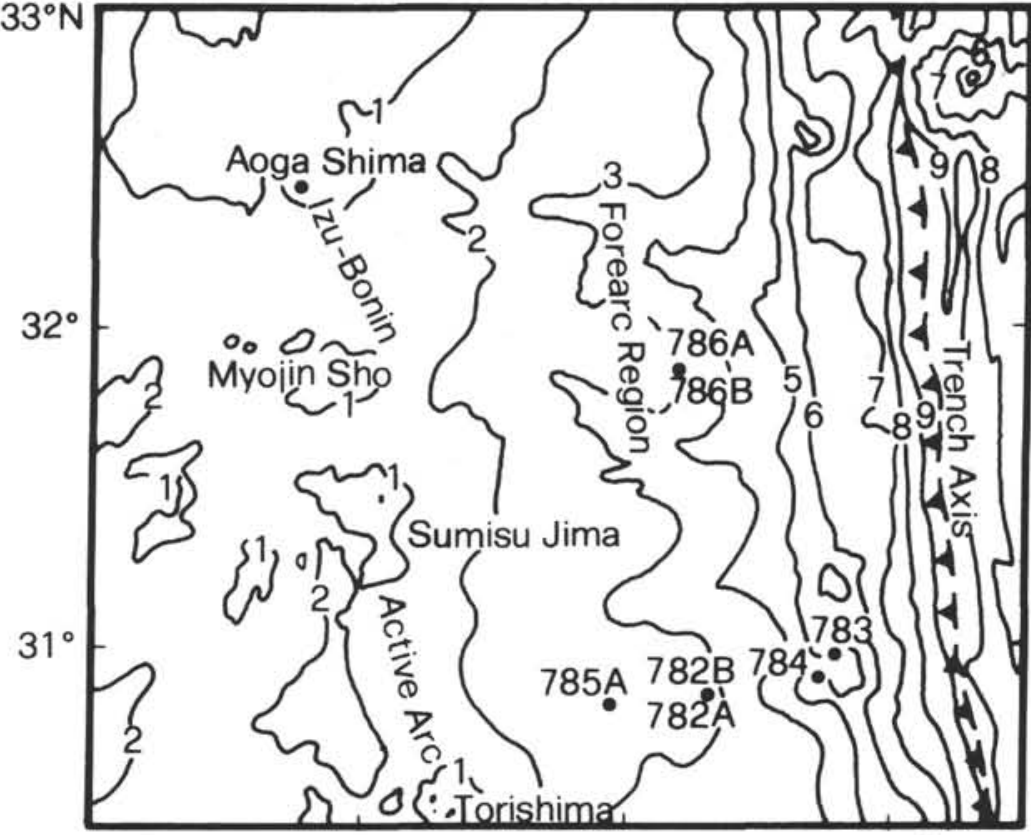

$\begin{array}{llll}139^{\circ} \mathrm{E} & 140^{\circ} & 141^{\circ} & 142^{\circ}\end{array}$ C

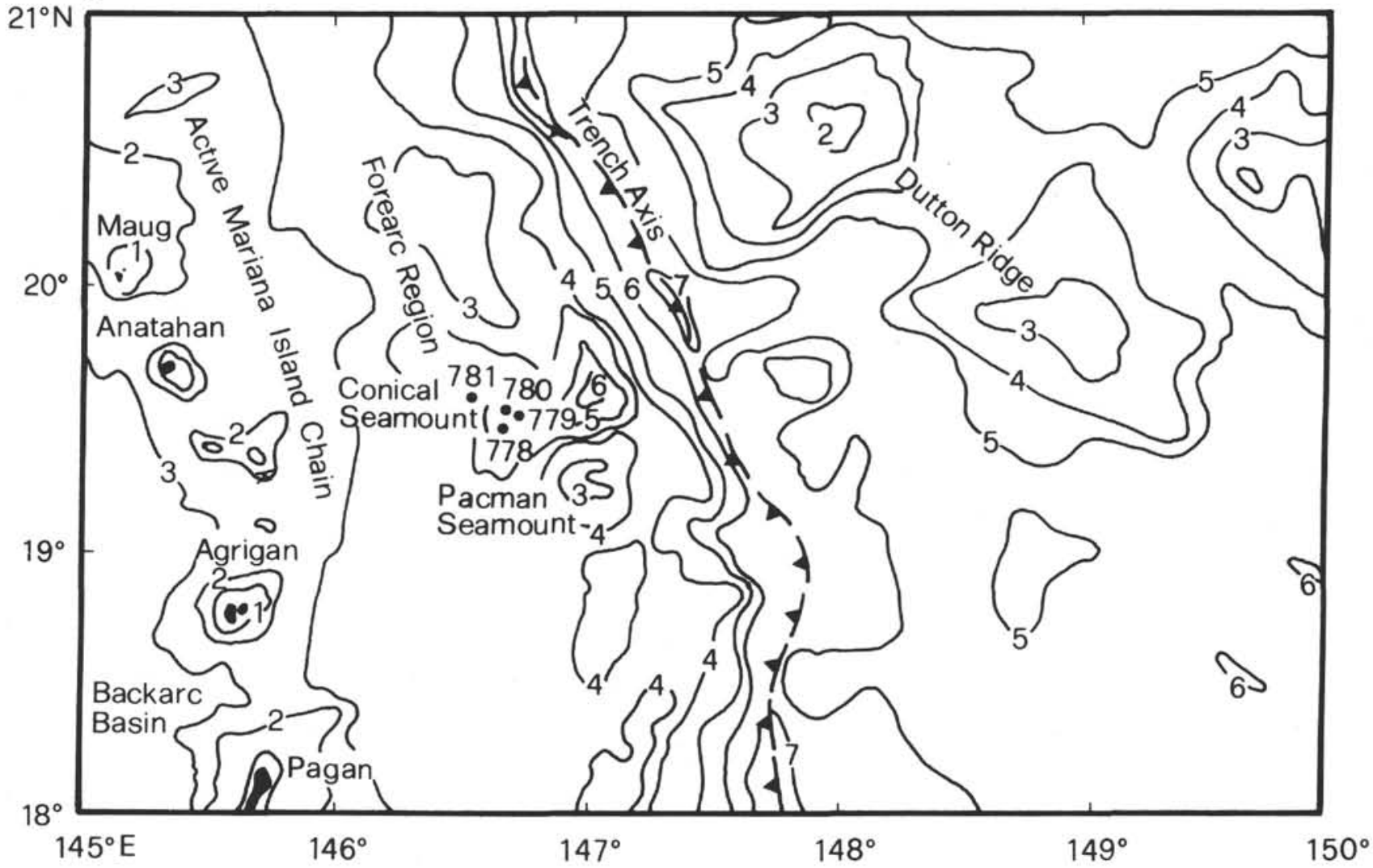

Figure 1. Location map of the sites drilled during Leg 125. 
H O LES

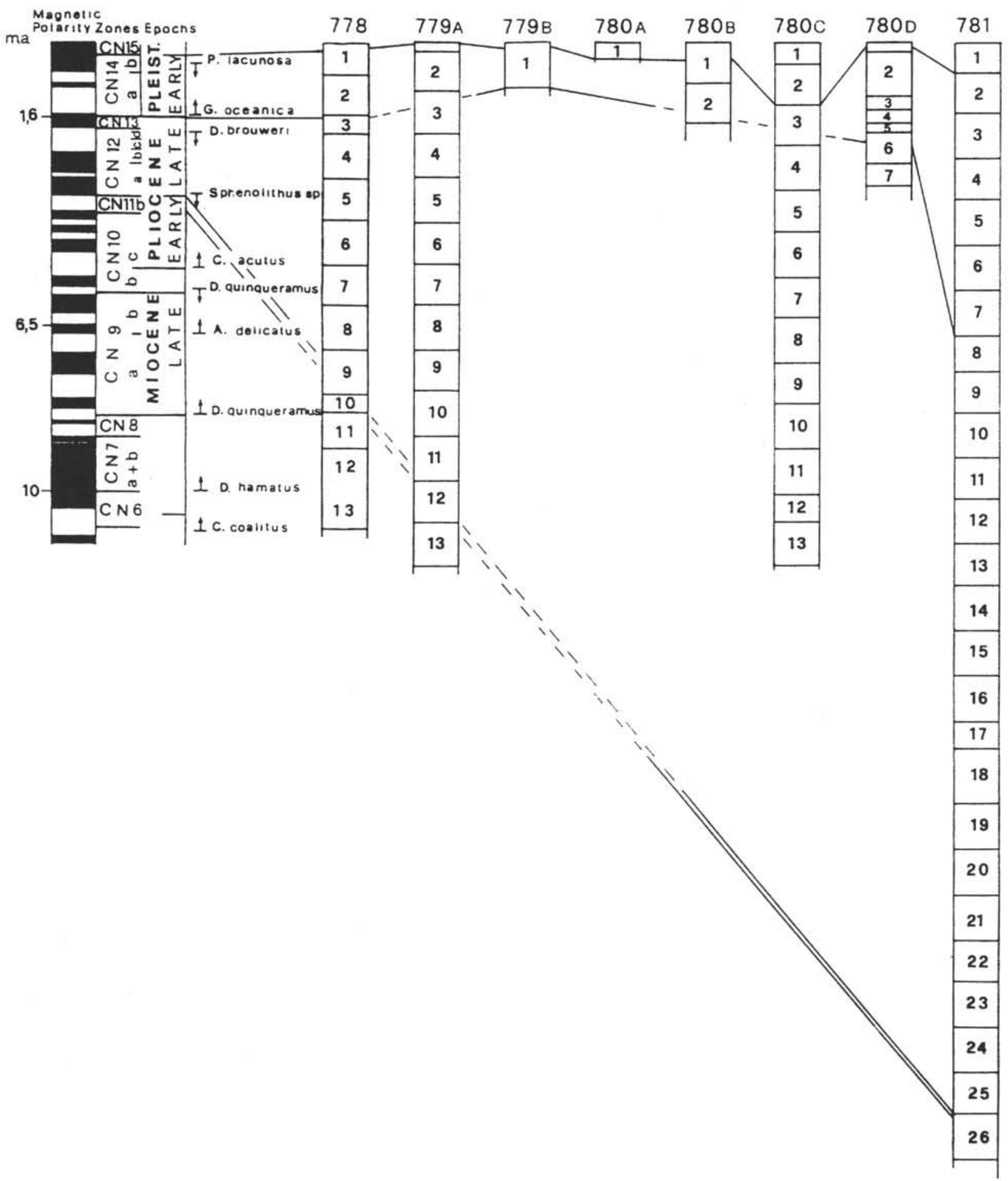

Figure 2. Correlation of Leg 125 drill sites in the Mariana area to the absolute time scale (after Berggren et al., 1985) and calcareous nannofossil zones (Okada and Bukry, 1980). 
Table 1. Distribution of calcareous nannofossils at Hole 781A. ${ }^{a}$

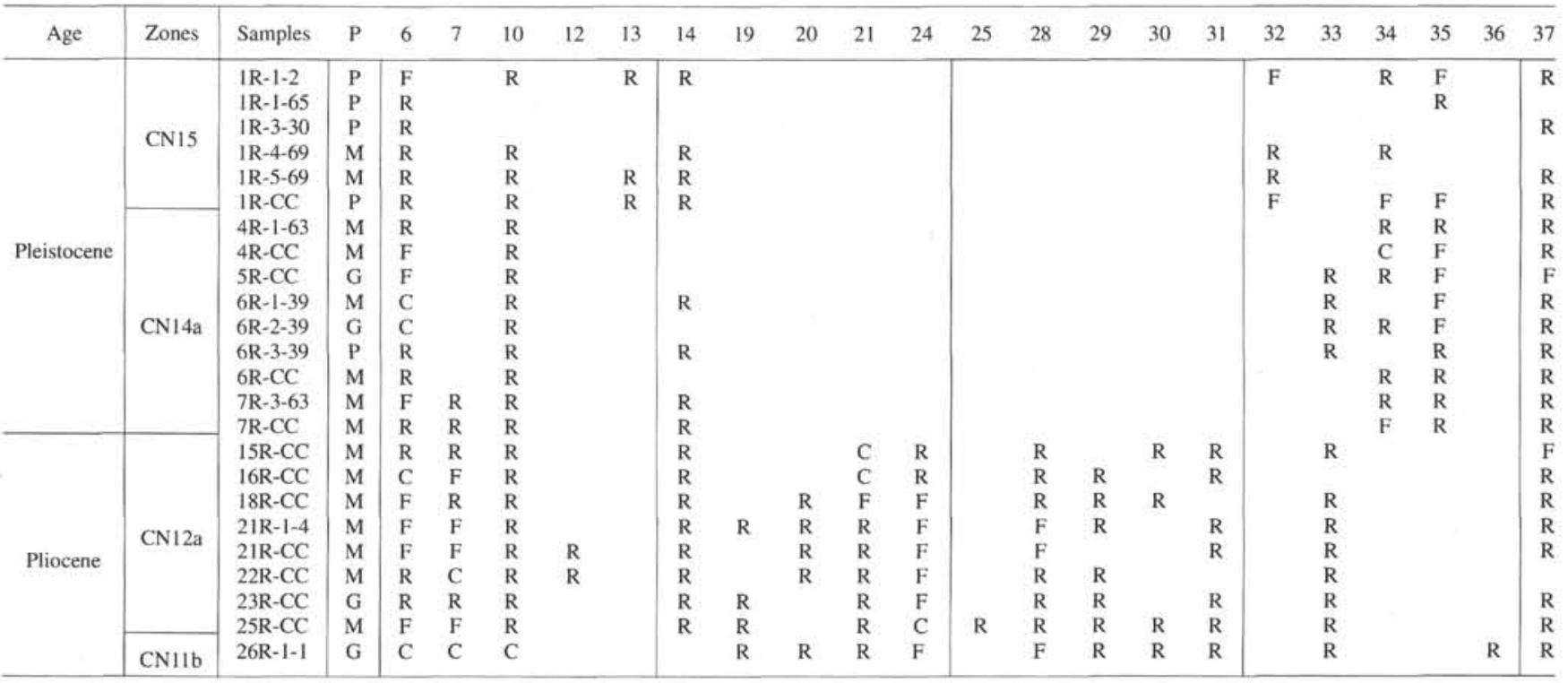

"See list for identification of species. $\mathrm{P}$ (preservation): $\mathrm{G}=\operatorname{good} ; \mathrm{M}=$ moderate; $\mathrm{P}=$ poor.

1. Amaurolithus amplificus

2. Amaurolithus bizzarrus

3. Amaurolithus delicatus

4. Amaumolithus primus

5. Amaurolithus tricomiculatus

6. Calcidiscus leptoporus

7. Calcidiscus macintyrei

8. Ceratolithus acutus

9. Ceratolithus armatus

10. Ceratolithus cristatus

II. Ceratolithus rugosus

12. Ceratolithus separatus

13. Ceratolithus simplex

14. Coccolithus pelagicus

15. Coccolithus pliopelagicus

16. Cricolithus jonesi

17. Dictyococcites aff. antarticus

18. Discoaster asymmetricus

19. Discoaster berggrenii

20. Discoaster blackstockae

21. Discoaster brouweri

22. Discoaster icarus
23. Discoaster intercalaris
24. Discoaster pentaradiatus
25. Discoaster quadramus
26. Discoaster quinqueramus
27. Discoaster stellulus
28. Discoaster surculus
29. Discoaster tamalis
30. Discoaster triradiatus
31. Discoaster variabilis
32. Emiliania huxleyi
33. Geminilithella rotula
34. Gephymocapsa caribbeanica
35. Gephymocapsa oceanica

\author{
36. Hayster perplexus \\ 37. Helicosphaera carteri \\ 38. Helicosphaera hyalina \\ 39. Helicosphaera inversa \\ 40. Helicosphaera neogranulata \\ 41. Helicosphaera sellii \\ 42. Helicosphaera sp. 1 \\ 43. Helicosphaera wallichi \\ 44. Oolithotus fragilis \\ 45. Ponthosphaera japonica \\ 46. Pontosphaera multipora \\ 47. Ponthosphaera sp. 1 \\ 48. Pseudoemiliania lacunosa \\ 49. Reticulofenestra pseudoumbilicus
}

\section{Izu-Bonin Region (Fig. 3)}

Sites 782 through 786 were drilled in the Izu-Bonin area.

Site $78230^{\circ} 51.6^{\prime} \mathrm{N}, 141^{\circ} 18.8^{\prime} \mathrm{E}$; water depth, $2959 \mathrm{mbsl}$

This site is located on the eastern margin of the Izu-Bonin forearc basin. A fine stratigraphic resolution was obtained from this site because of the high sedimentation rate, relatively good recovery, and the unusually low degree of dissolution.

The age of the recovered sediments is from middle Eocene to Holocene. The FAD (first appearance datum) of Amaurolithus primus and $A$. delicatus (base of CN9b Subzone) occurs in Sample 125-782A-21X-3, $119-120 \mathrm{~cm}$, at $196.29 \mathrm{mbsf}$. The top of the upper Miocene and the $\mathrm{CN} 10 \mathrm{a}$ Subzone were not detected because of poor recovery and/or because of the possible presence of a hiatus (see "Discussion" section, this chapter) (Tables 2,3). The early/late Pliocene boundary occurs above Sample $125-782 \mathrm{~A}-12 \mathrm{X}-3,82-83 \mathrm{~cm}$, at 109.12 mbsf. $^{3}$

\footnotetext{
${ }^{3}$ An unfortunate mistake is contained in Figure 3, page 204, of the Initial Reports volume for Leg 125 (Pearce, Fryer, et al., 1990); the early and late Pleistocene ages indicated for Cores $5 \mathrm{H}-12 \mathrm{X}$ and Cores $12 \mathrm{X}$ through $16 \mathrm{X}$, respectively, must be changed to early and late Pliocene.
}

The Pliocene/Pleistocene boundary (base of the CN14a Subzone) lies below Sample 125-782A-5H-2, 72-73 cm, at $40.52 \mathrm{mbsf}$, as identified by the first occurrence of Gephyrocapsa oceanica. At the top of Core 125-782A-1H, the acme of Emiliania huxleyi occurs. Contrary to the general good agreement between nannofossil biostratigraphy and magnetostratigraphy, there is a discrepancy in the Pleistocene interval between the nannofossil and magnetostratigraphic data (see also Stabell et al., this volume).

Site $78330^{\circ} 57.86^{\prime} \mathrm{N}, 141^{\circ} 47.27^{\circ} \mathrm{E}$; water depth, $4648.8 \mathrm{mbsl}$ Site $78430^{\circ} 54.49^{\prime} \mathrm{N}, 141^{\circ} 44.27^{\circ} \mathrm{E}$; water depth, $4900.8 \mathrm{mbsl}$

Both sites are located on a flank of a seamount on the inner wall of the Izu-Bonin Trench. They lie close to or below the calcite compensation depth (CCD), thus the calcareous nannofossils are often missing, or the associations are very poor and consist only of dissolution-resistant taxa or pieces of specimens such as proximal shields of Calcidiscus leptoporus.

The fossiliferous samples at Site 783 indicate a general early/middle Pleistocene age. At Site 784, the deeper fossiliferous Sample 125-784A-8R-3, 15-16 cm, contains a late Pliocene assemblage with Discoaster brouweri, Pseudoemiliania lacunosa, and Calcidiscus macintyrei. Above this sample, scattered samples with Gephyrocapsa 
Table 1 (continued).

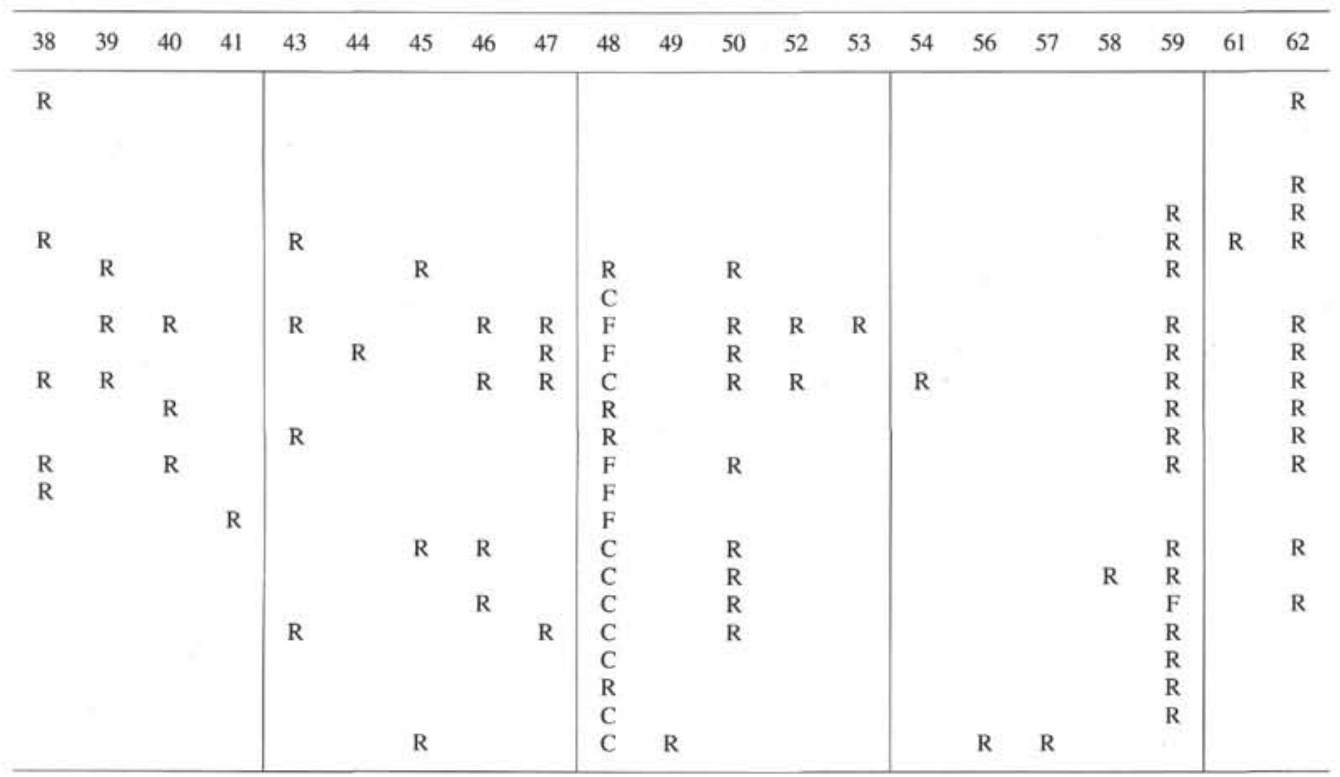

oceanica and Pseudoemiliania lacunosa give an early/middle Pleistocene age.

No range charts have been provided for these sites.

Site $78530^{\circ} 49.47^{\prime} \mathrm{N}, 140^{\circ} 55.17^{\prime} \mathrm{E}$; water depth, $2660.8 \mathrm{mbsl}$

The site is located in the center of the Izu-Bonin forearc basin. Early Pleistocene assemblages (Subzone $\mathrm{CN} 14 \mathrm{a}$ ), characterized by Pseudoemiliania lacunosa, Gephyrocapsa oceanica, Calcidiscus macintyrei, and Helicosphaera sellii, were found in the deepest fossiliferous sample (125-785A-7X-CC) (Table 4). The top of the core is of late Pleistocene age because of the occurrence of rare Emiliania huxleyi.

\section{Site $78631^{\circ} 52.5^{\prime} \mathrm{N}, 141^{\circ} 13.6^{\prime} \mathrm{E}$; water depth, $3062 \mathrm{mbsl}$}

The site is located in the center of the Izu-Bonin forearc basin north of Site 785. At this site, middle Eocene to early Pleistocene sediments were recovered (Table 5).

The sequence is very condensed, but within the Pliocene the sedimentation rate become slightly higher.

\section{BIOSTRATIGRAPHY}

\section{Amaurolithus primus Subzone (CN9b)}

Definition: Base, Amaurolithus primus FAD; top, Discoaster quinqueramus LAD. The subzone is represented at Holes 782A and 786A. However, only two samples represent Subzone CN9b in Site $786 \mathrm{~A}$; thus my remarks concern Hole $782 \mathrm{~A}$ almost exclusively.

Remarks: Reticulofenestra pseudoumbilicus usually dominates the assemblages in this subzone. Among the discoasters (after an initial domination by Discoaster quinqueramus/D. berggrenii), Discoaster variabilis is the dominant taxon.

The FAD's of Amaurolithus delicatus and A. primus occur simultaneously in Sample 125-782A-21X-3, 119-120 cm, at 196.29 mbsf. The base of Chron $6 \mathrm{~N}$ (Alì, this volume), corresponding to an estimated age of 6.5 Ma (Berggren et al., 1985), was found at 198.90 mbsf, which is $2.61 \mathrm{~m}$ below the first occurrence of Amaurolithus spp. Consequently the very high sedimentation rate in this subzone, at $2.61 \mathrm{~m}$, corresponds to $56 \mathrm{k} . \mathrm{y}$.
The first occurrence of Amaurolithus amplificus is in Sample $125-782 \mathrm{~A}-18 \mathrm{X}-\mathrm{CC}$, and its LAD is $6.0 \mathrm{~m}$ below the last occurrence of Discoaster quinqueramus and Triquetrorhabdulus rugosus.

Two distinct decreases in the abundance of Reticulofenestra pseudoumbilicus occur in the subzone. From bottom to top the first decrease (Fig. 4) is between Samples 125-782A-21X-1,119-120 cm, at $193.20 \mathrm{mbsf}$, and $125-782 \mathrm{~A}-20 \mathrm{X}-1,37-38 \mathrm{~cm}$, at $182.87 \mathrm{mbsf}$. The second decrease is at the top of the subzone. In both cases, peaks in the abundance of the probably cool species Dictyococcites aff. $D$. antarcticus can be observed.

The first of these events may be correlated to the well-known carbon shift at 6.2 Ma (Berggren et al., 1985; Keigwin and Shackleton, 1980; Keller et al., 1982). In fact, on the basis of the sedimentation rate, this event may be placed between 6.38 and $6.15 \mathrm{Ma}$, in connection with the lowermost decrease in ceratoliths (Fig. 5), while Coccolithus pelagicus increases (Fig. 4) and a change in the domi-nance of Discoaster quinqueramus/D. variabilis occurs (Fig. 5).

The second decrease in Reticulofenestra pseudoumbilicus occurs in Sample 125-782A-17X-1, 91-92 cm, and it may correspond to a cooling at the end of the late Miocene (Keller et al., 1982). In the same sample, the contemporaneous LAD of Discoaster quinqueramus and Triquetrorhabdulus rugosus can be seen.

At both Holes 782A and 786A, several sections were not recovered near the Miocene/Pliocene boundary (from Sections 125-782A-16X-6 to $125-782 \mathrm{~A}-16 \mathrm{X}-4$ and from Sections $125-786 \mathrm{~A}-4 \mathrm{X}-6$ to $125-786 \mathrm{~A}-$ $4 \mathrm{X}-2$ ); Subzone CN10a is completely missing, as well as the top of Subzone CN9b. However, three events suggest that the top of Subzone $\mathrm{CN} 9 \mathrm{~b}$ in Hole 782A is very close, i.e., the last occurrence of Amaurolithus amplificus in Sample 125-782A-17X-5, 91-92 cm, the LAD of Discoaster berggrenii, and the first occurrence of Discoaster icarus in Sample 125-782A-17X-2, 91-92 cm. However, problems exist with the $\mathrm{CN} 9 \mathrm{~b} / \mathrm{CN} 10 \mathrm{a}$ boundary (see "Discussion" section, this chapter).

\section{Ceratolithus acutus Subzone (CN10b)}

Definition: Base, Ceratolithus acutus FAD or Triquetrorhabdulus rugosus LAD; top, Ceratolithus acutus LAD or Ceratolithus rugosus FAD. The subzone has been identified only at Hole 782A.

Remarks: The Ceratolithus acutus FAD occurs in Sample 125$782 \mathrm{~A}-16 \mathrm{X}-\mathrm{CC}$ close to the base of the Thvera Subchron (Alì, this volume), estimated at an absolute age of $4.77 \mathrm{Ma}$ (Berggren et al., 
Table 2. Percent distribution of calcareous nannofossils at Hole 782A in the latest Miocene-early Pliocene interval, calculated after counting 500 specimens. ${ }^{a}$

\begin{tabular}{|c|c|c|c|c|c|c|c|c|c|c|c|c|c|c|c|c|c|c|c|c|}
\hline & Zones & Samples & $P$ & 1 & 2 & 3 & 4 & 5 & 6 & 7 & 8 & 9 & 10 & 11 & 14 & 16 & 17 & 18 & 19 & 20 \\
\hline & CNIIb & $\begin{array}{l}12 X-3-82 \\
12 X-4-47 \\
12 X-C C\end{array}$ & $\begin{array}{l}\text { G } \\
\text { G } \\
\text { M }\end{array}$ & & & & & & $\begin{array}{l}32.8 \\
43.5 \\
61.0\end{array}$ & $\begin{array}{r}18.6 \\
13.0 \\
7.6\end{array}$ & & & $\begin{array}{c}\mathrm{R} \\
0.8 \\
0.6\end{array}$ & & $\begin{array}{c}2.4 \\
R \\
0.6\end{array}$ & 0.6 & & $\begin{array}{l}0.4 \\
1.2 \\
0.6\end{array}$ & & $\mathrm{R}$ \\
\hline $\begin{array}{c}\text { early } \\
\text { Pliocene }\end{array}$ & CNIOC & $\begin{array}{l}13 X-1-108 \\
13 X-2-42 \\
13 X-3-92 \\
13 X-4-28 \\
13 X-C C \\
14 X-1-82 \\
14 X-2-62 \\
14 X-3-112 \\
14 X-4-4 \\
14 X-C C \\
15 X-1-5 \\
15 X-2-5 \\
15 X-3-5 \\
15 X-4-5 \\
15 X-5-5 \\
15 X-C C\end{array}$ & $\begin{array}{l}\mathrm{M} \\
\mathrm{G} \\
\mathrm{G} \\
\mathrm{P} \\
\mathrm{G} \\
\mathrm{P} \\
\mathrm{M} \\
\mathrm{G} \\
\mathrm{G} \\
\mathrm{M} \\
\mathrm{G} \\
\mathrm{G} \\
\mathrm{M} \\
\mathrm{P} \\
\mathrm{G} \\
\mathrm{M}\end{array}$ & & $\mathrm{R}$ & \begin{tabular}{|c|c|}
$R$ \\
$R$ \\
0.4 \\
0.2 \\
0.2 \\
$R$ \\
0.2 \\
0.2 \\
$R$ \\
$R$ \\
0.2 \\
0.8 \\
0.2 \\
0.2 \\
0.4 \\
$R$ \\
\\
0.2
\end{tabular} & $\begin{array}{c}\mathrm{R} \\
\mathrm{R} \\
\mathrm{R} \\
\mathrm{R} \\
\mathrm{R} \\
\mathrm{R} \\
0.2 \\
0.2 \\
\mathrm{R} \\
0.2\end{array}$ & $\begin{array}{c}\mathrm{R} \\
\\
\mathrm{R} \\
\mathrm{R} \\
\mathrm{R} \\
\\
0.4 \\
\mathrm{R} \\
0.2\end{array}$ & $\begin{array}{l}43.9 \\
44.4 \\
34.8 \\
36.3 \\
41.7 \\
33.4 \\
32.3 \\
27.4 \\
45.6 \\
29.3 \\
25.3 \\
41.6 \\
36.0 \\
49.3 \\
46.8 \\
31.3\end{array}$ & $\begin{array}{r}3.5 \\
2.7 \\
3.5 \\
3.2 \\
12.7 \\
2.4 \\
13.9 \\
4.0 \\
9.8 \\
4.7 \\
6.4 \\
3.8 \\
0.8 \\
4.8 \\
8.8 \\
7.0\end{array}$ & & & $\begin{array}{c}\mathrm{R} \\
0.4 \\
\mathrm{R} \\
\mathrm{R} \\
0.2 \\
0.2 \\
0.6 \\
0.2 \\
\mathrm{R} \\
\mathrm{R} \\
0.2\end{array}$ & R & $\begin{array}{l}0.6 \\
1.4 \\
0.6 \\
0.8 \\
3.7 \\
0.4 \\
2.0 \\
1.2 \\
0.6 \\
0.6 \\
0.6 \\
4.1 \\
2.0 \\
1.8 \\
3.0 \\
2.6\end{array}$ & & $\begin{array}{r}0.2 \\
\\
0.6 \\
0.4 \\
3.5 \\
19.3 \\
12.6 \\
5.0 \\
13.2\end{array}$ & $\begin{array}{l}\mathrm{R} \\
\mathrm{R} \\
\mathrm{R} \\
\mathrm{R} \\
\\
\\
0.2 \\
\mathrm{R} \\
\mathrm{R}\end{array}$ & & \\
\hline & CNIOb & $\begin{array}{l}16 \mathrm{X}-1-34 \\
16 \mathrm{X}-2-34 \\
16 \mathrm{X}-3-34 \\
16 \mathrm{X}-\mathrm{CC}\end{array}$ & $\begin{array}{l}\mathrm{M} \\
\mathrm{G} \\
\mathrm{M} \\
\mathrm{P}\end{array}$ & & & $\begin{array}{c}0.2 \\
0.6 \\
R \\
0.2\end{array}$ & $\begin{array}{l}\mathrm{R} \\
\mathrm{R}\end{array}$ & $\mathrm{R}$ & $\begin{array}{l}19.8 \\
25.5 \\
16.3 \\
21.4\end{array}$ & $\begin{array}{l}5.4 \\
4.3 \\
3.6 \\
6.8\end{array}$ & $\begin{array}{l}\mathrm{R} \\
\mathrm{R} \\
\mathrm{R}\end{array}$ & $\mathrm{R}$ & & & $\begin{array}{r}9.6 \\
12.3 \\
14.1 \\
15.4\end{array}$ & & $\begin{array}{l}39.0 \\
38.0 \\
45.0 \\
26.8\end{array}$ & & & $\mathrm{R}$ \\
\hline $\begin{array}{c}\text { late } \\
\text { Miocene }\end{array}$ & CN9b & $\begin{array}{l}17 X-1-91 \\
17 X-2-91 \\
17 X-3-91 \\
17 X-4-92 \\
17 X-5-91 \\
17 X-C C \\
18 X-1-28 \\
18 X-1-131 \\
18 X-2-28 \\
18 X-C C \\
19 X-1-35 \\
19 X-3-47 \\
19 X-C C \\
20 X-1-37 \\
20 X-C C \\
21 X-1-119 \\
21 X-2-119 \\
21 X-3-119\end{array}$ & $\begin{array}{l}\mathrm{M} \\
\mathrm{G} \\
\mathrm{M} \\
\mathrm{G} \\
\mathrm{M} \\
\mathrm{M} \\
\mathrm{G} \\
\mathrm{G} \\
\mathrm{M} \\
\mathrm{G} \\
\mathrm{G} \\
\mathrm{G} \\
\mathrm{P} \\
\mathrm{M} \\
\mathrm{M} \\
\mathrm{M} \\
\mathrm{M} \\
\mathrm{M}\end{array}$ & $\begin{array}{c}0.4 \\
\mathrm{R} \\
\mathrm{R} \\
\mathrm{R} \\
\mathrm{R}\end{array}$ & & $\begin{array}{c}\mathrm{R} \\
\mathrm{R} \\
0.4 \\
\mathrm{R} \\
0.4 \\
0.4 \\
0.6 \\
1.0 \\
0.4 \\
0.2 \\
\mathrm{R} \\
\mathrm{R}\end{array}$ & $\begin{array}{c}\mathrm{R} \\
\mathrm{R} \\
0.2 \\
\mathrm{R} \\
\\
\mathrm{R} \\
\mathrm{R}\end{array}$ & & $\begin{array}{r}31.3 \\
13.0 \\
11.4 \\
13.8 \\
24.4 \\
38.5 \\
21.1 \\
21.6 \\
16.8 \\
25.2 \\
8.3 \\
8.4 \\
46.9 \\
7.2 \\
17.8 \\
4.7 \\
10.0 \\
5.8\end{array}$ & $\begin{array}{l}5.6 \\
8.6 \\
3.6 \\
2.4 \\
1.2 \\
3.0 \\
2.1 \\
1.6 \\
2.0 \\
3.2 \\
\mathrm{R} \\
0.6 \\
3.2 \\
0.8 \\
0.4 \\
1.6 \\
2.6 \\
1.9\end{array}$ & & & & & $\begin{array}{r}7.1 \\
9.8 \\
5.2 \\
4.4 \\
2.6 \\
6.9 \\
10.7 \\
7.9 \\
8.6 \\
24.6 \\
20.3 \\
10.0 \\
15.4 \\
20.9 \\
16.7 \\
23.1 \\
28.8 \\
9.4\end{array}$ & & $\begin{array}{r}3.6 \\
20.8 \\
1.8 \\
4.2 \\
6.0 \\
4.7 \\
3.3 \\
R \\
R \\
R \\
0.2 \\
\\
0.2 \\
34.0 \\
27.3 \\
12.8 \\
11.8 \\
4.6\end{array}$ & & $\begin{array}{c}0.2 \\
0.2 \\
0.8 \\
0.6 \\
0.4 \\
R \\
0.8 \\
0.2 \\
0.6 \\
R \\
0.4 \\
1.0 \\
0.6 \\
2.0 \\
0.6 \\
1.2 \\
0.6\end{array}$ & $\mathrm{R}$ \\
\hline
\end{tabular}

\footnotetext{
"See list in Table I for identification of species. The letter code R indicates taxa observed out of count.
}

1985), at 148.05 mbsf. Note that the integrated magnetostratigraphy and biostratigraphy worked out by Chanell et al. (1990) for the Tyrrhenian Sea drill sites during ODP Leg 107 documented that the base of the Pliocene falls just beneath the Thvera Subchron, and has an estimated age of approximately $4.85 \mathrm{Ma}$. As the top of Subzone $\mathrm{CN} 10 \mathrm{~b}$, in accordance with Berggren et al. (1985), is dated at $4.6 \mathrm{Ma}$ and the bottom at $5.0 \mathrm{Ma}$, most of the subzone is missing, together with all of Subzone CN10a. Because of the high sedimentation rate, it is unlikely that about $1 \mathrm{~m}$.y. is represented by only three sections. A hiatus between the late Miocene and the early Pliocene may be present, as it occurs near DSDP Site 296 (Keller et al., 1982).

Ceratolithus acutus is very rare through the subzone, and the top of the subzone was recognized by the LAD of Ceratolithus armatus which has an almost identical distribution. Amaurolithus tricorniculatus has its FAD together with Ceratolithus acutus.

The associations are dominated by Dictyococcites aff. D. antarcticus, which seems to reach its acme in Sample 125-782A-16X-3, 33-34 cm. Then the taxon rapidly decreases. However, the record of the acme may be incomplete because of poor recovery. Reticulofenestra pseudoumbilicus has its minimum (less than 5\%) in this subzone. Through the subzone a remarkable change in the composition of the assemblages occurs (Fig. 4). Coccolithus pelagicus falls to averages less than $5 \%$ and is not an important constituent of the associations for the complete
Pliocene interval, while Calcidiscus leptoporus increases and is consistently abundant in the assemblages. Remarkable changes also were recorded among the discoasters (Fig. 5). Discoaster variabilis still dominates in the first sample of the subzone, then it decreases from about $50 \%$ to $6 \%$ at the top of the subzone, and becomes subordinate among discoasters species. On the contrary, Discoaster brouweri and especially D. surculus increase and along with Discoaster pentaradiatus become the main representatives of the genus Discoaster.

\section{Ceratolithus rugosus Subzone (CN10c)}

Definition: Base, Ceratolithus rugosus FAD or Ceratolithus acutus LAD; top, Amaurolithus primus and/or Amaurolithus tricorniculatus LAD. The subzone was recognized at Holes 782A and 786A.

Remarks: Ceratolithus rugosus is very rare and scattered; more common is $C$. cristatus, which in both holes has its first occurrence within the subzone.

At the top of the subzone in Hole 782A, all species of Amaurolithus become extinct in less than $0.2 \mathrm{~m}$.y. A. tricorniculatus becomes extinct in Sample 125-782A-13X-CC; A. primus in Sample 125$782 \mathrm{~A}-13 \mathrm{X}-3,92-93 \mathrm{~cm}$, but Sections 125-782A-13X-6 through 125782-13X-4 (in part) are missing; and A. delicatus becomes extinct in Sample 125-782A-13X-1, 101-102 cm. At Hole 786A, A. tricor- 
Table 2 (continued).

\begin{tabular}{|c|c|c|c|c|c|c|c|c|c|c|c|c|c|c|c|c|c|c|c|c|c|c|}
\hline 21 & 22 & 23 & 24 & 25 & 26 & 27 & 28 & 29 & 30 & 31 & 33 & 37 & 41 & 42 & 45 & 46 & 48 & 49 & 51 & 54 & 55 & 56 \\
\hline 2.0 & & & 3.8 & & & & 2.0 & 0.2 & $\mathrm{R}$ & 0.4 & 4.0 & 0.4 & $\mathrm{R}$ & & & & 26.4 & 0.4 & & & & 1.8 \\
\hline 7.1 & & & 4.4 & & & & 7.5 & 0.6 & 1.0 & 0.4 & 8.1 & 0.6 & & & 0.2 & & 10.5 & 0.4 & & & & 0.6 \\
\hline 4.4 & & & 4.0 & & & & 5.8 & 0.6 & $\mathrm{R}$ & 0.8 & 3.4 & 1.2 & $\mathrm{R}$ & & R & & 7.8 & 0.8 & & & & 0.6 \\
\hline 1.0 & & & 4.5 & & & & 2.0 & & & 0.2 & 1.0 & 0.4 & & & 0.2 & & & 39.3 & & & & 1.4 \\
\hline 0.6 & & & 2.5 & & & & 1.0 & & $\mathrm{R}$ & 1.0 & 3.3 & 1.6 & & & & & & 37.8 & & & R & 2.3 \\
\hline 2.0 & & & 3.0 & 0.2 & & & 3.7 & & 0.2 & 0.8 & 2.3 & 0.8 & $\mathrm{R}$ & & $\mathbf{R}$ & & & 41.2 & & & & 3.0 \\
\hline 0.6 & & & 1.2 & $\mathrm{R}$ & & & 1.6 & & & 1.4 & 2.0 & 0.8 & & & $\mathrm{R}$ & & & 50.2 & & & & 0.6 \\
\hline 0.2 & & & 1.0 & & & & 1.6 & & & 0.6 & 3.7 & 1.8 & $\mathrm{R}$ & & $\mathrm{R}$ & & & 28.3 & & & & 3.1 \\
\hline 2.4 & & & 0.6 & & & & 4.0 & & $\mathrm{R}$ & 1.0 & 2.6 & 1.8 & & & $\mathrm{R}$ & & & 48.4 & & & & 1.3 \\
\hline 2.6 & & & 5.0 & $\mathrm{R}$ & & & 7.4 & & $\mathrm{R}$ & 3.4 & 1.0 & 0.6 & & & & & & 27.3 & & & & 2.2 \\
\hline 3.2 & & & 5.2 & & & & 1.4 & & & 2.0 & 2.6 & 0.2 & 0.2 & & & & & 50.8 & & & $\mathrm{R}$ & 1.0 \\
\hline 1.4 & & & 2.4 & & & & 2.2 & & 0.2 & $\mathrm{R}$ & 0.8 & 0.6 & 0.2 & 0.2 & & & & 35.4 & & & & 0.6 \\
\hline 2.0 & & & 3.1 & & & & 2.4 & & $\mathrm{R}$ & 0.4 & 1.4 & 0.2 & & & & & & 52.4 & & & & 1.2 \\
\hline 5.2 & & & 2.6 & & & & 1.6 & & $\mathrm{R}$ & 1.4 & 1.2 & $\mathrm{R}$ & & & & & & 52.7 & & & & 1.0 \\
\hline 6.0 & & & 5.6 & & & & 4.2 & & $\mathrm{R}$ & 0.2 & 3.0 & 0.2 & 0.2 & & & & & 26.0 & & & & 0.6 \\
\hline 11.9 & & & 4.2 & & & & 8.0 & & 0.2 & 0.8 & 2.8 & & & & & & & 9.8 & & & & 0.8 \\
\hline 5.4 & & & 4.4 & & & & 4.2 & & $\mathrm{R}$ & 0.2 & 6.4 & 0.6 & & & & 0.2 & & 4.4 & & & & 2.2 \\
\hline 1.6 & & & 3.2 & & & 0.2 & 2.6 & & $\mathrm{R}$ & 1.4 & 6.2 & 1.4 & 0.2 & 0.2 & 0.2 & $\mathrm{R}$ & & 13.6 & & $\mathrm{R}$ & & 2.4 \\
\hline 3.4 & & & 3.6 & & & 0.2 & 4.2 & & & 1.0 & 5.6 & 0.8 & & & & & & 24.8 & & & & 1.0 \\
\hline 0.8 & & & 1.8 & & & 0.4 & 1.4 & & $\mathrm{R}$ & 4.8 & 3.0 & 3.6 & & 0.6 & 0.4 & $\mathrm{R}$ & & 6.6 & & & & 1.2 \\
\hline 1.4 & & & 1.6 & & & 0.2 & 1.2 & & & 1.9 & 4.1 & 1.2 & & $\mathrm{R}$ & 0.2 & $\mathrm{R}$ & & 4.7 & & & & 2.5 \\
\hline 1.0 & & 0.4 & 2.6 & & & 0.2 & 3.4 & & & 6.0 & & $\mathrm{R}$ & & & & & & 3.2 & & & & 2.0 \\
\hline 1.4 & & $\mathrm{R}$ & 2.4 & & & 0.8 & 3.0 & & & 12.6 & 3.0 & $\mathrm{R}$ & & & & & & 4.6 & & & & 0.8 \\
\hline $\mathrm{R}$ & & $\mathrm{R}$ & 2.0 & & 0.4 & $\mathrm{R}$ & 0.2 & & $\mathrm{R}$ & 4.0 & 0.8 & 1.2 & & & $\mathrm{R}$ & & & 59.3 & & & & 1.2 \\
\hline 0.2 & & $\mathrm{R}$ & 2.2 & & 1.6 & & $\mathrm{R}$ & & $\mathrm{R}$ & 1.8 & 2.8 & 1.0 & & $\mathrm{R}$ & 0.2 & & & 33.6 & & & & 2.5 \\
\hline 1.4 & $\mathrm{R}$ & $\mathrm{R}$ & 1.0 & & 2.0 & & 1.2 & & $\mathrm{R}$ & 30.8 & 0.2 & & & & & & & 38.2 & & & & 0.8 \\
\hline 1.6 & & & 1.2 & & 4.8 & $\mathrm{R}$ & 0.2 & & 0.4 & 7.0 & 0.8 & 0.2 & & $\mathrm{R}$ & & $\mathrm{R}$ & & 55.0 & & & & 2.8 \\
\hline 1.2 & & $\mathrm{R}$ & 1.8 & & 3.2 & $\mathrm{R}$ & 0.2 & & $\mathrm{R}$ & 12.4 & 0.6 & 0.2 & & & & & & 41.8 & & & & 1.9 \\
\hline 0.6 & & $\mathrm{R}$ & 1.6 & & 2.0 & 0.2 & $\mathrm{R}$ & & 0.2 & 4.3 & 1.6 & 2.0 & & & $\mathrm{R}$ & & & 26.5 & & & & 5.3 \\
\hline 0.6 & & $\mathrm{R}$ & 1.0 & & 2.5 & & $\mathrm{R}$ & & $\mathrm{R}$ & 3.6 & 2.9 & 2.8 & & $\mathrm{R}$ & $\mathbf{R}$ & & & 44.4 & & & & 1.5 \\
\hline 0.6 & & $\mathrm{R}$ & 3.2 & & 2.1 & $\mathbf{R}$ & 0.6 & & $\mathrm{R}$ & 11.0 & 1.6 & 0.2 & & & & & & 46.9 & & & & 0.4 \\
\hline 0.2 & & $\mathrm{R}$ & 2.4 & & 6.6 & 0.2 & 0.2 & & $\mathrm{R}$ & 7.6 & 2.0 & 0.2 & & $\mathrm{R}$ & R & $\mathrm{R}$ & & 48.3 & & & & 2.4 \\
\hline 0.2 & & & 1.4 & & 2.8 & 0.4 & 0.2 & & $\mathrm{R}$ & 4.6 & 2.2 & 3.0 & & 0.2 & 0.2 & & & 25.0 & $\mathrm{R}$ & & 0.2 & 4.4 \\
\hline 0.2 & & & 0.6 & & 0.2 & & $\mathrm{R}$ & & & 2.6 & 2.8 & 0.6 & & & & & & 61.7 & & & & 1.9 \\
\hline 1.0 & & & 2.2 & & 1.6 & & 0.8 & & $\mathrm{R}$ & 4.2 & 1.0 & R & & & & & & 67.5 & & & & 1.8 \\
\hline 1.6 & & $\mathrm{R}$ & 3.0 & & 4.6 & 0.4 & & & & 14.0 & 0.4 & 0.6 & & & & & & 7.4 & & & & 0.6 \\
\hline 0.6 & & $\mathrm{R}$ & 0.6 & & 1.8 & $\mathrm{R}$ & $\mathrm{R}$ & & & 5.6 & 1.0 & 0.6 & & & $\mathrm{R}$ & & & 25.6 & & & & 0.8 \\
\hline 4.0 & & $\mathrm{R}$ & 1.4 & & 3.0 & 0.6 & & & $\mathrm{R}$ & 5.4 & 3.0 & 0.2 & & & & & & 17.0 & & & & 1.6 \\
\hline 0.8 & & $\mathrm{R}$ & 0.2 & & 1.0 & & 0.2 & & & 3.6 & $\mathrm{R}$ & $\mathrm{R}$ & & & & & & 50.3 & & & & 0.6 \\
\hline 1.4 & & $\mathrm{R}$ & 0.8 & & 3.4 & & $\mathrm{R}$ & & $\mathrm{R}$ & 1.4 & 1.0 & 0.4 & & & & & & 36.4 & & & & 0.4 \\
\hline 1.5 & & $\mathrm{R}$ & 1.5 & & 3.7 & & $\mathrm{R}$ & & & 3.5 & 1.2 & 0.4 & & & & & & 65.0 & & & & 0.4 \\
\hline
\end{tabular}

niculatus also predates the $A$. primus and $A$. delicatus extinctions, which occur simultaneously in Sample 125-786A-3H-1, 85-86 cm. However, this sample shows a mixed assemblage in which the LAD's of Reticulofenestra pseudoumbilicus and of Sphenolithus spp. and the FAD of Pseudoemiliania lacunosa occur.

At Hole 782A, Calcidiscus leptoporus dominates the associations through the first third of the subzone, then Reticulofenestra pseudoumbilicus quickly increases, becoming again the most abundant taxon in the assemblages. The ceratoliths and in particular Amaurolithus delicatus have an acme in the middle of the subzone (Sample 125$782 \mathrm{~A}-15 \mathrm{X}-1,5-6 \mathrm{~cm})$. In the same sample, Ceratolithus cristatus has its first occurrence and Reticulofenestra pseudoumbilicus increases.

Among discoasters, D. brouweri dominates in the lower third of the subzone, then $D$. pentaradiatus and $D$. surculus become dominant, the acme of the latter occurring in Sample 125-782A-14X-2, $62-63 \mathrm{~cm}$. Discoaster variabilis shows a relative peak just below the D. surculus acme and, in accordance with Backman and Shackleton (1983), decreases in the upper Gilbert Chron. A small acme of Sphenolithus abies was observed at the top of the subzone in accord- ance with Ellis (1982). At both sites, the FAD of Helicosphaera sellii is recorded at the base of the subzone, through which it is always rare.

At Hole 786A, the species abundance are similar (Fig. 6), although precise correlations are difficult because of the condensed sequence. Severe etching was observed at the bottom of the subzone at Hole $782 \mathrm{~A}$.

The modest in length Sphenolithus neoabies Subzone (CN11a) has been not detected.

\section{Discoaster asymmetricus Subzone (CN11b)}

Definition: Base, Discoaster asymmetricus acme; top, Reticulofenestra pseudoumbilicus and Sphenolithus spp. LAD.

The subzone was recorded at Hole $782 \mathrm{~A}$ and probably at Hole $781 \mathrm{~A}$. In the latter site, the oldest fossiliferous sediments contain mixed associations from early and late Pliocene. Sample 125-781A$26 \mathrm{R}-1,17-18 \mathrm{~cm}$, contains an assemblage that is compatible with this subzone if Reticulofenestra pseudoumbilicus and Sphenolithus spp. have not been reworked. 
Table 2 (continued).

\begin{tabular}{|c|c|c|c|c|c|c|}
\hline & Zones & Samples & $\mathrm{P}$ & 57 & 59 & 60 \\
\hline \multirow[b]{2}{*}{$\begin{array}{c}\text { early } \\
\text { Pliocene }\end{array}$} & CNIIb & $\begin{array}{l}12 X-3-82 \\
12 X-4-47 \\
12 X-C C\end{array}$ & $\begin{array}{l}\text { G } \\
\text { G } \\
\text { M }\end{array}$ & $\begin{array}{l}1.4 \\
0.2\end{array}$ & $\begin{array}{l}0.4 \\
0.2\end{array}$ & \\
\hline & $\mathrm{CN} 10 \mathrm{c}$ & $\begin{array}{l}13 X-1-108 \\
13 X-2-42 \\
13 X-3-92 \\
13 X-4-28 \\
13 X-C C \\
14 X-1-82 \\
14 X-2-62 \\
14 X-3-112 \\
14 X-4-4 \\
14 X-C C \\
15 X-1-5 \\
15 X-2-5 \\
15 X-3-5 \\
15 X-4-5 \\
15 X-5-5 \\
15 X-C C\end{array}$ & $\begin{array}{c}M \\
G \\
G \\
P \\
G \\
P \\
M \\
G \\
G \\
M \\
G \\
G \\
M \\
P \\
G \\
M\end{array}$ & $\begin{array}{l}0.6 \\
1.0 \\
1.4 \\
1.2 \\
1.0 \\
0.8 \\
0.8 \\
0.6 \\
0.4 \\
1.6 \\
0.4 \\
0.2 \\
0.6 \\
3.4 \\
1.0 \\
0.9\end{array}$ & & \\
\hline \multirow[b]{2}{*}{$\begin{array}{c}\text { late } \\
\text { Miocene }\end{array}$} & $\mathrm{CN} 10 \mathrm{~b}$ & $\begin{array}{l}16 X-1-34 \\
16 X-2-34 \\
16 X-3-34 \\
16 X-C C\end{array}$ & $\begin{array}{l}M \\
G \\
M \\
P\end{array}$ & $\begin{array}{l}1.4 \\
0.6 \\
1.0 \\
0.3\end{array}$ & & \\
\hline & $\mathrm{CN} 9 \mathrm{~b}$ & $\begin{array}{l}17 X-1-91 \\
17 X-2-91 \\
17 X-3-91 \\
17 X-4-92 \\
17 X-5-91 \\
17 X-C C \\
18 X-1-28 \\
18 X-1-131 \\
18 X-2-28 \\
18 X-C C \\
19 X-1-35 \\
19 X-3-47 \\
19 X-C C \\
20 X-1-37 \\
20 X-C C \\
21 X-1-119 \\
21 X-2-119 \\
21 X-3-119\end{array}$ & $\begin{array}{l}M \\
\text { G } \\
M \\
\text { G } \\
M \\
M \\
\text { G } \\
\text { G } \\
\text { M } \\
\text { G } \\
\text { G } \\
\text { G } \\
\text { P } \\
M \\
M \\
M \\
M \\
M\end{array}$ & $\begin{array}{l}1.2 \\
1.4 \\
1.2 \\
0.4 \\
0.8 \\
1.8 \\
1.1 \\
0.4 \\
1.0 \\
1.6 \\
0.6 \\
0.4 \\
0.8 \\
R \\
\\
\\
0.6 \\
0.4 \\
0.4\end{array}$ & & $\begin{array}{c}\mathrm{R} \\
0.2 \\
0.6 \\
\mathrm{R} \\
\mathrm{R} \\
\mathrm{R} \\
0.4 \\
\mathrm{R} \\
\mathrm{R} \\
\mathrm{R} \\
\mathrm{R} \\
0.2\end{array}$ \\
\hline
\end{tabular}

Remarks: The bottom of the subzone is characterized, in addition to the Discoaster asymmetricus acme, by the FAD's of Pseudoemiliania lacunosa, Discoaster decorus, and D. tamalis.

The Discoaster asymmetricus FAD is in the lower part of Subzone $\mathrm{CN} 10 \mathrm{c}$, but until Subzone $\mathrm{CN} 11 \mathrm{~b}$, it is very rare and scattered. Pseudoemiliania lacunosa is initially small and not common, but quickly increases in size and abundance through the subzone. In the lower latitude Hole 781 A, it is usually more common and larger.

At the top of the subzone, the coeval extinction of Reticulofenestra pseudoumbilicus and Sphenolithus abies, S. neoabies, and S. moriformis occurs.

Associations are different in the middle-latitude Hole 782 A and in the low-latitude Hole 781A. In the former, the assemblages are dominated by Calcidiscus leptoporus and, among discoasters, by Discoaster brouweri, followed by D. pentaradiatus. In Hole $781 \mathrm{~A}$, discoasters are clearly more abundant and dominate the associations, with Discoaster pentaradiatus and D. surculus together with Pseudoemiliania lacunosa. At both sites, Calcidiscus macintyrei is common, while Reticulofenestra pseudoumbilicus is very rare.

\section{Discoaster tamalis Subzone (CN12a)}

Definition: Base, Reticulofenestra pseudoumbilicus and Sphenolithus spp. LAD; top, Discoaster tamalis LAD. The subzone is represented at the Holes 781A. 782A, and 786A.

Remarks: Toward the top of the subzone, the termination of the Discoaster asymmetricus acme slightly predates the Discoaster tamalis LAD at Holes 782A and 786A (Figs. 5, 6), and more considerably at Hole 781A (Fig. 7). Discoaster variabilis, usually very rare, becomes extinct within the subzone.

Calcidiscus leptoporus and/or Pseudoemiliania lacunosa dominate the associations until the end of the late Pliocene at Holes 782A and 786A, and discoasters and $P$. lacunosa dominate at Hole 781A.

Among discoasters, a remarkable pattern is the dominance of Discoaster pentaradiatus, which was found at in all three sites. The end of the Discoaster pentaradiatus dominance occurs just below the top of the subzone in Holes 781 A and 786A (Figs. 6, 7), and at both sites contemporaneously, the dominance of Discoaster brouweri begins. In Hole $782 \mathrm{~A}$, after a decrease at the top of the subzone, $D$. pentaradiatus has another peak of abundance $(61 \%)$ in Subzone $\mathrm{CN} 12 \mathrm{~b}$ (Fig. 5).

A decrease in abundance of discoasters has been linked to the cooling event at about 2.4 Ma (Backman and Pestiaux, 1987; Rio et al., 1990). This event is very near to the base of the Matuyama Chron (Berggren et al., 1985) and to the top of Subzone CN12b. Alì (this volume) found the base of the Matuyama Chron at Hole 786A, at 4.65 mbsf, which corresponds to the top of Section 125-786A-1H-4. But the LAD's of Discoaster tamalis and of D. variabilis (top of Subzone CN12a) occur in Sample 125-786A-1H-3, 96-97 cm, at $3.96 \mathrm{mbsf}$, together with a decrease in the number of discoasters. In Sample 125-786A-1H-4, 92-93 cm, at 5.42 mbsf, the change between Discoaster pentaradiatus and $D$. brouweri dominance occurs. Almost the same sequence of events is recorded at Hole 781A. The LAD of Discoaster variabilis occurs in Sample 125-781A-16R-CC, and in the preceding available Sample 125-781A-18R-CC, the LAD of Discoaster tamalis, changes in the dominance of Discoaster pentaradiatus/D. brouweri, and the decrease in abundance of discoasters are recorded. At Hole 782A, these events (with the Discoaster surculus LAD, instead of that of D. tamalis) occur at the top of Subzone $\mathrm{CN} 12 \mathrm{~b}$. Thus, it is probable that at both Holes 781A and 786A, Discoaster tamalis and D. variabilis have been reworked; moreover, $D$. variabilis is always rare and scattered in Subzone CN12a and $D$. tamalis is also rare.

Other bioevents are recorded along with the change in dominance of $D$. pentaradiatus $/ D$. brouweri: the decrease of ceratoliths, the contemporaneous or very near extinction of Ceratolithus separatus, and the occurrence of Coccolithus pliopelagicus, which has been recorded only in this interval of the late Pliocene.

Another interesting magnetostratigraphic datum comes from Hole $786 \mathrm{~A}$. Ali (this volume) found at $17.60 \mathrm{mbsf}$ (Section 125-786A-2H6) the polarity interval Gauss Chron with an estimate absolute age of 3.18 Ma (Berggren et al., 1985). This age is near that of other well-known indications of global cooling (Shackleton and Opdyke, 1977; Thunell, 1979). The sample containing Ali's datum is $131 \mathrm{~cm}$ below the beginning of the Discoaster pentaradiatus dominance. On the basis of sedimentation rates, the 3.2 Ma event, at Hole 782A occurs at $105.72 \mathrm{mbsf}, 52 \mathrm{~cm}$ above the base of the D. pentaradiatus event, in Sample 125-782A-12X-1, 84-85 cm. Also in this case, one can note a decrease in discoasters (except at Hole 781A) and ceratoliths and an increase of dissolution (Hole 782A). Discoaster asymmetricus and $D$. tamalis contemporaneously show the highest percentage values supporting the hypothesis of a cooler water preference of these 


\section{HOLES}

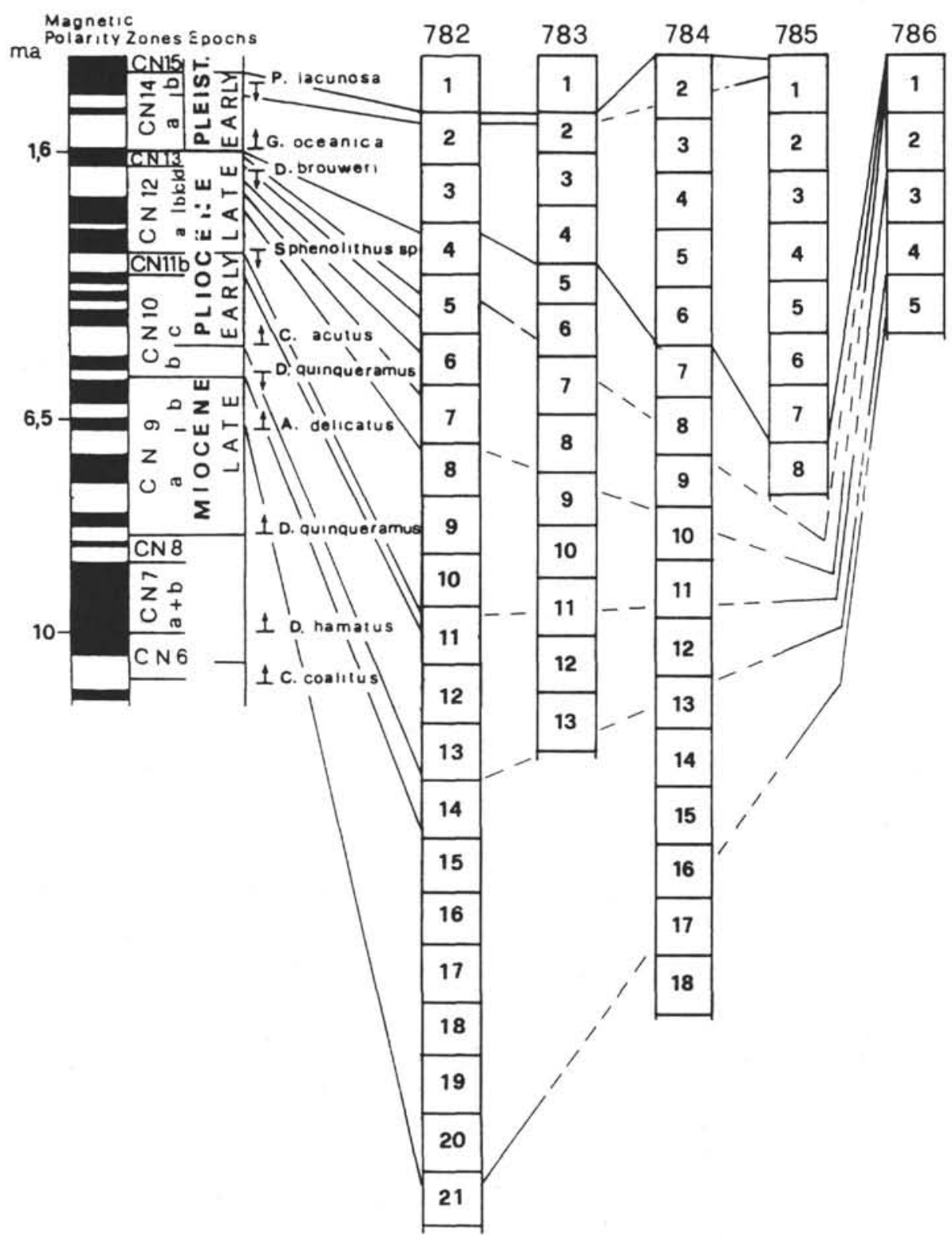

Figure 3. Correlation of Leg 125 drill sites in the Izu-Bonin area to the absolute time scale (after Berggren et

taxa with respect to $D$. pentaradiatus (Rio et al., 1990). By contrast Discoaster surculus undergoes a distinct decrease. In the upper part of the subzone, Pontosphaera japonica, Syracosphaera pulchra, and Helicosphaera sellii increase.

\section{Discoaster surculus Subzone (CN12b)}

Definition: Base, Discoaster tamalis LAD; top, Discoaster surculus LAD. The subzone was detected at Holes 782A and 786A.

Remarks: Discoaster surculus, before its extinction at the top of the subzone, shows a distinct peak (53\%) at the Gauss/Matuyama boundary (Fig. 5), just found by Backman and Shackleton (1983). Above the $D$. surculus peak, D. pentaradiatus reaches another maximum (61\%) and rapidly decreases to $9 \%$ at the bottom of Subzone CN12c.

Near the bottom of the subzone, discoasters and ceratoliths are still common; afterward they became rare, and Calcidiscus leptoporus, C. macintyrei, Coccolithus pelagicus, and Pseudoemiliania lacunosa dominate the associations. Dissolution is severe throughout the subzone.

\section{Discoaster pentaradiatus Subzone (CN12c)}

Definition: Base, Discoaster surculus LAD; top, Discoaster pentaradiatus LAD. The subzone was recorded only at Hole 782A. 
$\begin{array}{llll}\text { C. leptoporus } \% & \text { C. peiagicus } \% & \text { R.pseudoumbilicus } \% & \text { D. aff. antarticus } \%\end{array}$

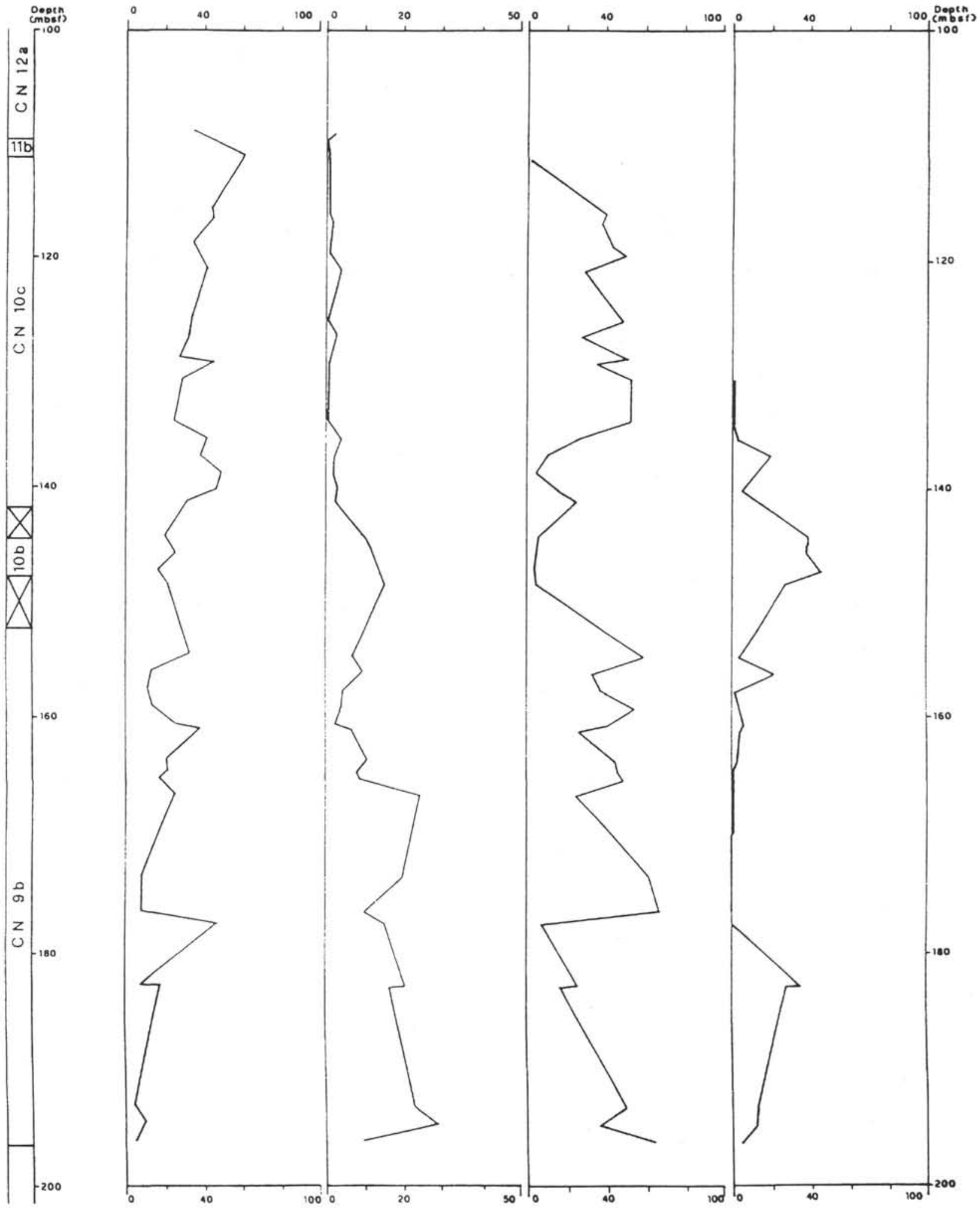

Figure 4. Percent of abundance of selected species in the latest Miocene-early Pliocene interval at Hole 782A, evaluated by counting at least 500 specimens. 
Remarks: Discoaster brouweri dominates among discoasters, with peaks of more than $90 \%$ (Fig. 5). At the base and at the top of the subzone, large Pseudoemiliania lacunosa dominate the associations, together with Calcidiscus leptoporus, C. macintyrei, and Coccolithus pelagicus. Large specimens of Discoaster brouweri and of still rare D. triradiatus, are also present. Ceratolithus cristatus reaches its acme, with robust morphotypes, at the $\mathrm{CN} 12 \mathrm{c} / \mathrm{CN} 12 \mathrm{~d}$ boundary. Toward the middle of the subzone, the assemblages became poor and were etched.

\section{Calcidiscus macintyrei Subzone (CN12d)}

Definition: Base, Discoasterpentaradiatus LAD; top, Discoaster brouweri $\mathrm{LAD}$. The subzone was detected only at Hole 782A.

Remarks: Through the first third of the subzone, Discoaster triradiatus increases, and the assemblages are rich and diversified. From this point, samples are very rich in volcanic ashes, and the assemblages become poor. In particular, discoasters become too rare to be counted in a sufficient number of specimens.

The Discoaster brouweri LAD occurs in Sample 125-782A-6H, $121-122 \mathrm{~cm}$, at $53.51 \mathrm{mbsf}$. Ali (this volume) reports the base of the Olduvai, 1.88 Ma according to Berggen et al.(1985), at $50.53 \mathrm{mbsf}$; this extinction datum is in perfect accordance with the interpretation of Backman and Shackleton (1983). Helicosphaera sellii is rather frequent throughout the subzone.

\section{Emiliania annula Subzone (CN13a)}

Definition: Base, Discoaster brouweri LAD; top, Gephyrocapsa caribbeanica FAD. Samples referable to this subzone are found only at Hole 782A.

Remarks: The assemblages, usually abundant and diversified, are dominated by Pseudoemiliania lacunosa and Calcidiscus leptoporus, together to small Prinsiaceae difficult to determine. Calcidiscus macintyrei, Coccolithus pelagicus, and Helicosphaera carteri are also frequent. Helicosphaera sellii and Rhabdosphaera clavigera increase upward; usually, large Ceratolithus cristatus are present with a variable frequency. Umbellosphaera irregularis has its first occurrence within the subzone.

\section{Gephyrocapsa caribbeanica Subzone (CN13b)}

Definition: Base, Gephyrocapsa caribbeanica FAD; top, Gephyrocapsa oceanica FAD. This short subzone was recorded at Holes $782 \mathrm{~A}$ and 786A.

Remarks: The association undergoes a few changes with respect to the previous subzone. Calcidiscus macintyrei and Coccolithus pelagicus decrease through the subzone. Gephyrocapsa caribbeanica, rare at the bottom, increases rapidly; Syracosphaera pulchra becomes larger and frequent.

\section{Emiliania ovata Subzone (CN14a)}

Definition: Base, Gephyrocapsa oceanica FAD; top, Pseudoemiliania lacunosa LAD. The subzone was detected at Holes 778A, $779 \mathrm{~B}, 781 \mathrm{~A}, 782 \mathrm{~A}$, and 786 A in both the Mariana and Izu-Bonin areas. But in Holes 778 A and 779B, only few fossiliferous samples were found and the associations are very poor and sometimes mixed.

Remarks: To avoid confusion in the names of this subzone and for $\mathrm{CN13}$, the two species names have been preserved (Okada and Bukry, 1980), although the two taxa are considered as younger synonyms of Pseudoemiliania lacunosa. The subzone was subdivided on the basis of the events pointed out by Gartner (1977).

Several problems complicated the interpretation of the biostratigraphical analysis in this subzone. These were: (1) reworking, (2) the often poor and badly preserved associations, and, above all, (3) the discrepancy between magnetostratigraphic and biostratigraphic data at
Hole 782A. Most of the biostratigraphic problems derive from $\mathrm{Cal}$ cidiscus macintyrei and partly from Helicosphaera sellii. The latter species is usually very rare and scattered through the subzone, thus it is difficult to detect its LAD. The Calcidiscus leptoporus/C. macintyrei group was subdivided on the basis of the size of the distal shield, which is larger than $10 \mu \mathrm{m}$ for Calcidiscus macintyrei (see Backman and Shackleton, 1983). The group is represented in the subzone, among others, by a lot of specimens between 9 and $10 \mu \mathrm{m}$ in size; only few specimens are larger than or equal to $11 \mu \mathrm{m}$. Sometimes they have certainly been reworked, as in Sample 125-781A-1R-CC, where Calcidiscus macintyrei $(11 \mu \mathrm{m})$, together with Discoaster variabilis and Pseudoemiliania lacunosa, is associated with Emiliania huxleyi.

At Hole 782A, the first occurrence of Gephyrocapsa oceanica is recorded in Sample 125-782A-5H-2, 72-73 cm. The first morphotypes of $G$. oceanica are small, with a bridge at a high angle with the short axis, (see Bergen, 1984). Milner (Fryer, Pearce, Stokking, et al., 1990) placed the base of the Pleistocene, based on planktonic foraminifers, in Sample 125-782A-4H-CC. Alì (this volume) found the base of the Jaramillo event, $(0.98 \mathrm{Ma})$, at the bottom of Section $125-782 \mathrm{~A}-4 \mathrm{H}-4$, at $34.6 \mathrm{mbsf}$. Sediments are $27,31 \mathrm{~m}$ thick in this subzone; on the basis of the sedimentation rate calculated for this subzone, $34.6 \mathrm{~m}$ might correspond to $1.49 \mathrm{Ma}$. On the other hand, the last occurrence of Calcidiscus macintyrei, more than $10 \mu \mathrm{m}$ in size, usually is placed at $1.45 \mathrm{Ma}$ (Backman and Shackleton, 1983), occurs in Sample 125-782A-3H-1, 58-59 cm, at 19.88 mbsf, which corresponds to $0.76 \mathrm{Ma}$ on the basis of the sedimentation rate. Thus, the paleomagnetic and biostratigraphic data are inconsistent. Nevertheless, biostratigraphic events logically follow one another; in Sample 125-782A-2H-CC, the LAD of Helicosphaera sellii occurs, the "small Gephyrocapsa" interval event follows between Samples 125 $782 \mathrm{~A}-2 \mathrm{H}-6,38-39 \mathrm{~cm}$, and $125-782 \mathrm{~A}-2 \mathrm{H}-4,52-53 \mathrm{~cm}$, and at only $1.61 \mathrm{~m}$ above, the Pseudoemiliania lacunosa LAD occurs. An explanation might be a strong decrease of the sedimentation rate from the bottom of the subzone toward its top. Indeed volcanic ashes are present at the top of Core $125-782 \mathrm{~A}-4 \mathrm{H}$ and are particularly abundant in the second half of Core 125-782A-3H. But this cannot explain the magnetostratigraphic datum that comes from the lower part of the interval under discussion.

In the lower part of the subzone, a short interval is dominated by large Gephyrocapsa, of the G. caribbeanica type having an angled bridge with respect to the short axis, a small central opening, and a wide collar. Within this interval, the first typical large Gephyrocapsa oceanica appear that have a low angled bridge with respect to the short axis.

The last occurrence of Pontosphaera japonica lies just below the LAD of Calcidiscus macintyrei at Holes 781A, 782A, and 785A; the LAD of the former has been placed at the bottom of the subzone by Ellis (1982), but it has been also reported from the living plankton (Reid, 1980). Helicosphaera inversa has its first occurrence above the Calcidiscus macintyrei LAD at Hole 781 A, at the top of the "small Gephyrocapsa" event at Hole 782A, and within Subzone CN14b at Hole 785A.

At Hole 782A, Calcidiscus leptoporus and/or Pseudoemiliania lacunosa dominate, among larger placoliths, the assemblages of the subzone before the LAD of Calcidiscus macintyrei, when Gephyrocapsa oceanica increases and goes from common to abundant. Pseudoemiliania lacunosa decreases at the top of the subzone, where it is rare. The usually poor associations of Holes $781 \mathrm{~A}$ and $785 \mathrm{~A}$ only partially confirm this pattern.

\section{Ceratolithus cristatus Subzone (CN14b)}

Definition: Base, Pseudoemiliania lacunosa LAD; top, Emiliania huxleyi FAD. This short subzone was recorded only at Hole 782A.

Remarks: Abundant taxa through the subzone are Calcidiscus leptoporus, Gephyrocapsa oceanica, and G. caribbeanica. 

D. pentaradiatus $\%$
D. variabilis $\%$
D. surculus $\%$
D. brouweri\%

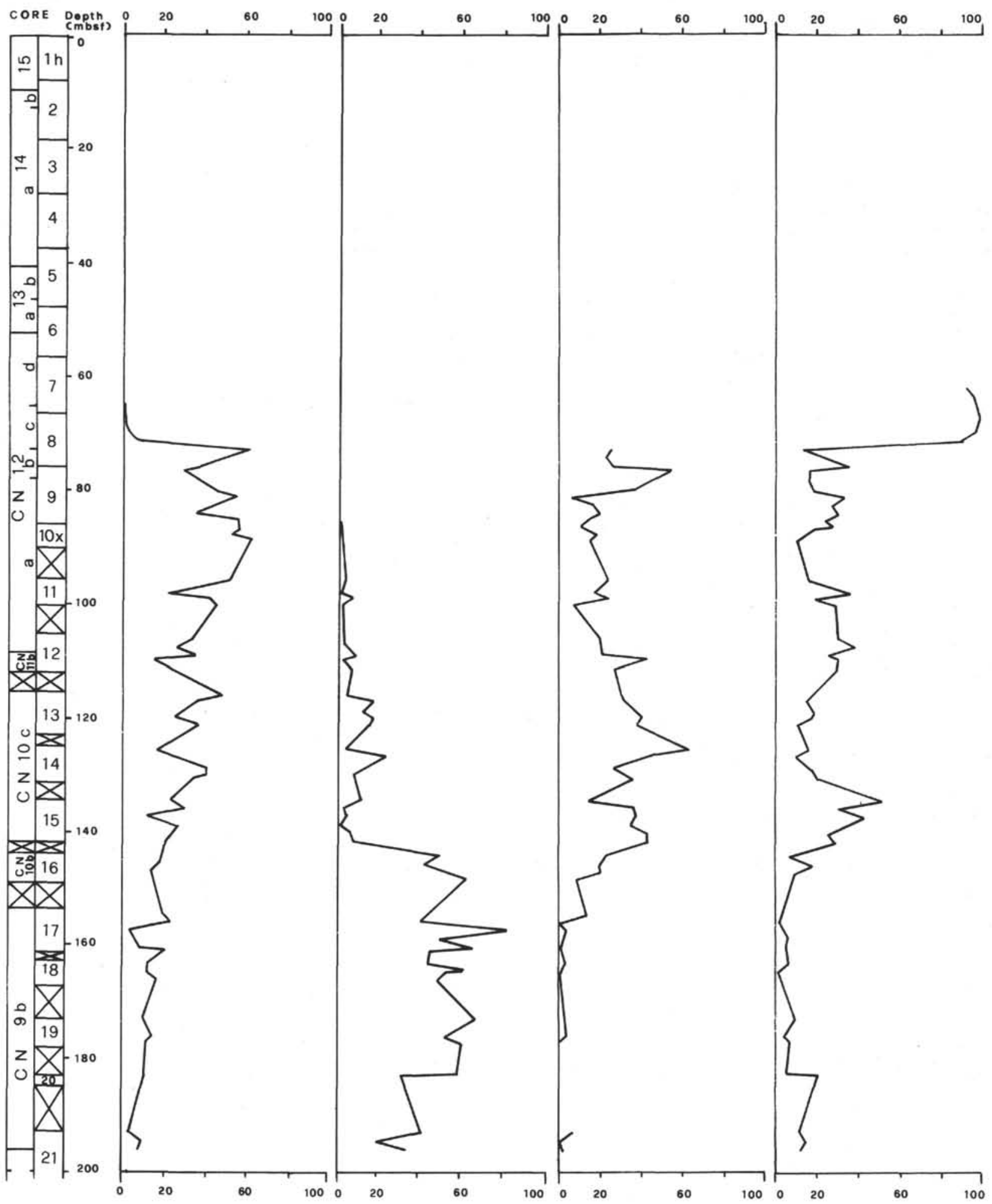

Figure 5. Percent of abundance of selected discoaster species at Hole 782A contained in 300 specimens of the genus. Number of ceratoliths and Amaurolithus delicatus with respect to 300 discoasters. The top of the D. brouweri curve does not correspond to its LAD (see text). 
D. asymmetricus $\%$ D. tamalis $\%$
D. quinqueramus $\%$
D. berggreni\%

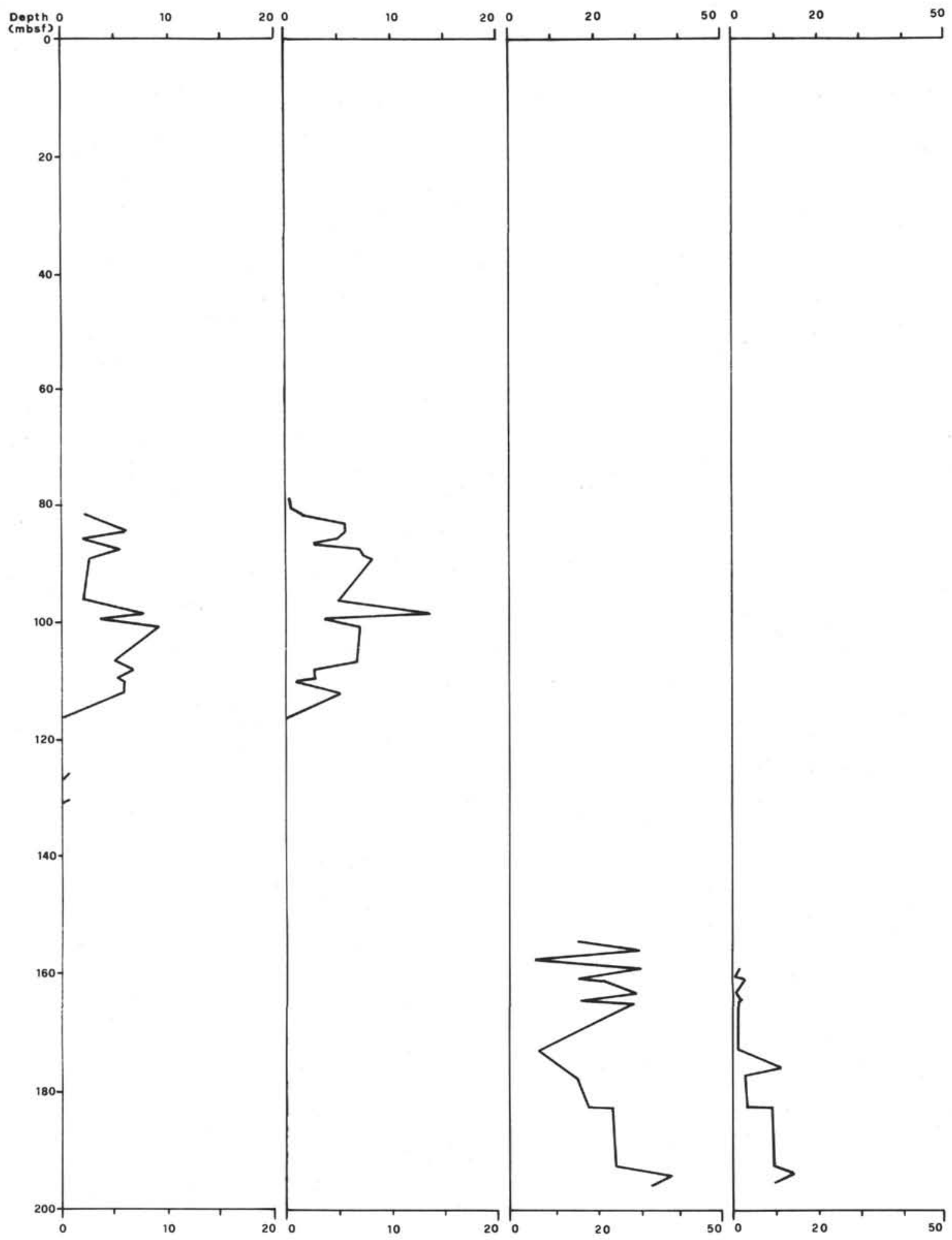

Figure 5 (continued). 


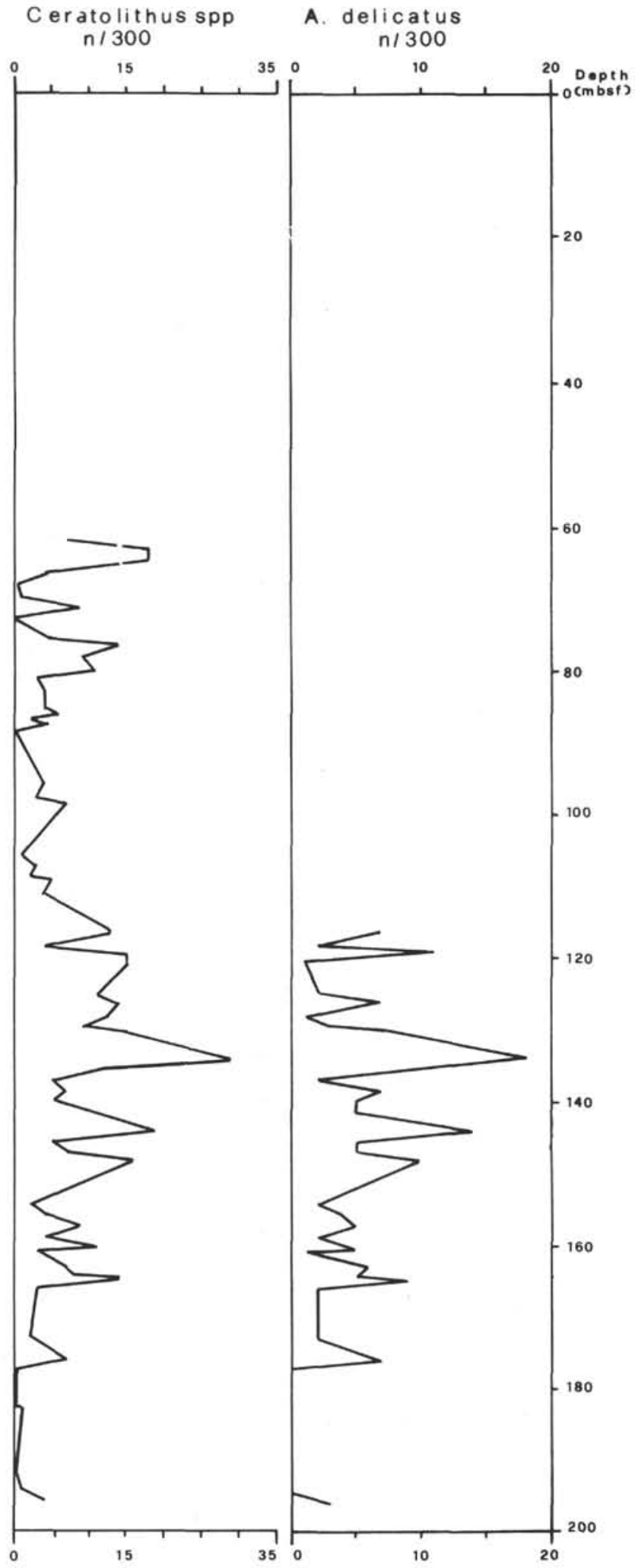

Figure 5 (continued).

\section{Emiliania huxleyi Zone (CN15)}

Definition: Base, Emiliania huxleyi FAD. The zone was detected in Holes 779A, 779B, 780A through 780D, 781 A, 782A, and 785A.

Remarks: At Hole 782A, at the bottom of the zone, Emiliania huxleyi is small and not very frequent; toward the top of the core, (Sample 125-782A-1H-2, 12-13 cm), it becomes larger, 2-3 $\mu \mathrm{m}$, and abundant. This level corresponds to the "Emiliania huxleyi Acme Zone" (Gartner, 1977). Contemporaneously to the Emiliania huxleyi increase, Gephyrocapsa caribbeanica has a decrease and becomes rare (Thierstein et al., 1977; Rio et al., 1990). Gephyrocapsa oceanica also increases again, from common to abundant, just below the $E$. huxleyi acme, also increasing in size (larger or equal to $5 \mu \mathrm{m}$ ). An alternative zonal marker might be Ceratolithus simplex, which, in all the holes, is present only in this zone.

No major qualitative differences between temperate and tropical Pleistocene associations are recorded in these holes. Usually in the tropics, specimens are larger, especially Gephyrocapsa oceanica and Pseudoemiliania lacunosa; the former, moreover, has a wider central opening and is comparatively more abundant. Hayaster perplexus and Oolithotus fragilis are present exclusively in low-latitude sites.

\section{QUANTITATIVE INVESTIGATIONS OF SELECTED TAXA}

This discussion refers chiefly to the results of the quantitative analyses performed on the assemblages in the latest Miocene/early Pliocene interval and on the discoasters and ceratoliths between the latest Miocene and late Pliocene. Data are from the following holes: (1) $781 \mathrm{~A}$, from the top of the early Pliocene to late Pliocene (poor recovery); (2) 782A, from late Miocene to late Pliocene; and (3) $786 \mathrm{~A}$, from late Miocene to late Pliocene (condensed sequence).

\section{Ceratoliths}

Ceratoliths are widespread in the samples, even though they are usually rare in the assemblages. The genus Amaurolithus has its first occurrence with Amaurolithus delicatus and A. primus at Holes $782 \mathrm{~A}$ and 786A. Amaurolithus amplificus appears at Hole 782A, on the basis of the sedimentation rate, at about 5.9 Ma near the base of Chron 5 , in accordance with Mazzei et al. (1979). The last occurrence of this taxon is in Sample 125-782A-17X-5, 91-92 cm, at 160.51 mbsf, with a calculated age, on the basis of the sedimentation rate, of $5.54 \mathrm{Ma}$. Its LAD predates slightly the last occurrence of Discoaster quinqueramus and Triquetrorhabdulus rugosus, which occur in Sample 125-782A-17X-1,91-92 cm, and of Discoaster berggrenii in Sample 125-782A-17X-2, 91-92 cm.

Mazzei et al. (1979) recorded the LAD of A. amplificus at 5.6 Ma, predating the last occurrence of $D$. quinqueramus and $D$. berggrenii that occurs toward the top of Chron 5, Subchron A, at about 5.3-5.4 $\mathrm{Ma}$ and corresponding to the top of Subzone $\mathrm{CN1Oa}$ in accordance with Berggren et al. (1985). Ellis (1982) placed the A. amplificus extinction at the top of the WPN27a Subzone $(=C N 10$ a Subzone of Okada and Bukry, 1980) after the LAD of D. quinqueramus and D. berggrenii. Okada and Rio (in Backman, Duncan, et al., 1990) achieved the same conclusions as Mazzei et al. (1979) with the difference that the LAD of $D$. quinqueramus has been placed at 5.0 Ma. Gartner and Bukry (1975) write "...and it disappears (A. amplificus) from the records at about the level of the first occurrence of Ceratolithus acutus"; the FAD of $C$. acutus defines the bottom of 
Table 3. Distribution of calcareous nannofossils at Hole $782 \mathrm{~A}$ in the late Pliocene-late Pleistocene interval. ${ }^{\mathrm{a}}$

\begin{tabular}{|c|c|c|c|c|c|c|c|c|c|c|c|c|c|c|c|c|c|c|c|c|c|c|c|}
\hline Age & Zones & Samples & $\mathrm{P}$ & 6 & 7 & 10 & 12 & 13 & 14 & 15 & 16 & 18 & 21 & 24 & 25 & 28 & 29 & 30 & 31 & 32 & 33 & 34 & 35 \\
\hline & & $1 \mathrm{H}-1-2$ & G & A & & $\mathbf{R}$ & & $\mathrm{R}$ & $\mathrm{F}$ & & & & & & & & & & & A & & $\mathrm{F}$ & A \\
\hline & & IH-2-12 & G & A & & $\mathbf{R}$ & & & $\mathbf{R}$ & & & & & & & & & & & C & $\mathrm{R}$ & $\mathrm{R}$ & C \\
\hline & & $1 \mathrm{H}-3-12$ & $\mathrm{M}$ & C & & $\mathrm{R}$ & & & $\mathrm{R}$ & & & & & & & & & & & $\mathrm{F}$ & & & C \\
\hline & $\mathrm{CN} 15$ & $1 \mathrm{H}-4-12$ & G & A & & $\mathrm{R}$ & & $\mathrm{R}$ & $\mathrm{F}$ & & & & & & & & & & & $\mathrm{F}$ & & $\mathrm{F}$ & A \\
\hline & & $1 \mathrm{H}-5-11$ & M & C & & $\mathrm{R}$ & & $\ddot{R}$ & $\mathrm{R}$ & & & & & & & & & & & $\mathrm{F}$ & & & C \\
\hline & & $1 \mathrm{H}-6-12$ & $\mathrm{M}$ & C & & $\mathrm{R}$ & & $\mathrm{R}$ & $\mathrm{F}$ & & & & & & & & & & & $\mathrm{F}$ & & $\mathrm{C}$ & $\mathrm{F}$ \\
\hline & & IH.CC & $\mathrm{M}$ & C & & $\mathrm{R}$ & & $\mathrm{R}$ & $\mathrm{F}$ & & & & & & & & & & & $\mathrm{F}$ & & $\mathrm{F}$ & C \\
\hline & $\mathrm{CN} 14 \mathrm{~b}$ & $2 \mathrm{H}-1-53$ & $\mathrm{M}$ & C & & $\mathrm{R}$ & & & $\mathrm{F}$ & & & & & & & & & & & & & C & C \\
\hline & CNI & $2 \mathrm{H}-2-83$ & $\mathrm{M}$ & C & & $\mathrm{R}$ & & & $\mathrm{F}$ & & & & & & & & & & & & & $\mathrm{C}$ & $\mathrm{F}$ \\
\hline & & $2 \mathrm{H}-3-4 \mathrm{I}$ & G & $\mathrm{F}$ & & $\mathrm{R}$ & & & $\mathrm{R}$ & & & & & & & & & & & & & $\mathrm{C}$ & $\mathrm{F}$ \\
\hline & & $2 \mathrm{H}-4-52$ & $\mathrm{M}$ & & & & & & & & & & & & & & & & & s & $\mathrm{m}$ & $\mathrm{a}$ & 1 \\
\hline & & $2 \mathrm{H}-5-3 \mathrm{I}$ & $\mathrm{M}$ & & & & & & & & & & & & & & & & & s & $\mathrm{m}$ & a & 1 \\
\hline & & $2 \mathrm{H}-6-38$ & G & & & & & & & & & & & & & & & & & s & $\mathrm{m}$ & a & 1 \\
\hline & & $2 \mathrm{H}-\mathrm{CC}$ & G & C & & & & & $\mathrm{R}$ & & $\mathrm{R}$ & & & & & & & & & & & $\mathrm{C}$ & A \\
\hline Pleistocene & & $3 \mathrm{H}-1-58$ & G & A & $\mathrm{F}$ & & & & $\mathrm{F}$ & & & & & & & & & & & & & & A \\
\hline Plemstocene & & $3 \mathrm{H}-2-88$ & $\mathrm{P}$ & C & $\mathrm{R}$ & $\mathrm{R}$ & & & $\mathrm{F}$ & & & & & & & & & & & & & $\mathrm{F}$ & C \\
\hline & & $3 \mathrm{H}-3-99$ & M & A & $\mathrm{R}$ & $\mathrm{R}$ & & & $\mathrm{R}$ & & & & & & & & & & & & $\mathrm{R}$ & $\mathrm{C}$ & $\mathrm{R}$ \\
\hline & & $3 \mathrm{H}-4-69$ & $\mathrm{P}$ & A & $\mathrm{R}$ & $\mathrm{R}$ & & & & & & & & & & & & & & & & $\mathrm{C}$ & $\mathrm{F}$ \\
\hline & & $3 \mathrm{H}-5-69$ & $\mathrm{P}$ & C & $\mathrm{R}$ & & & & $\mathrm{R}$ & & & & & & & & & & & & & & $\mathrm{R}$ \\
\hline & $\mathrm{CN} 14 \mathrm{a}$ & $3 \mathrm{H}-6-85$ & G & A & $\mathrm{F}$ & & & & C & & & & & & & & & & & & & $\mathrm{F}$ & $\mathrm{R}$ \\
\hline & & $3 \mathrm{H}-7-3 \mathrm{I}$ & $\mathrm{M}$ & A & $\mathrm{R}$ & & & & $\mathrm{R}$ & & $\mathrm{R}$ & & & & & & & & & & & $\mathrm{C}$ & $\mathrm{F}$ \\
\hline & & $4 \mathrm{H}-1-23$ & $\mathrm{M}$ & C & $\mathrm{R}$ & $\mathrm{R}$ & & & $\mathrm{R}$ & & & & & & & & & & & & & A & $\mathrm{F}$ \\
\hline & & $4 \mathrm{H}-2-15$ & M & C & $\mathrm{R}$ & $\mathrm{R}$ & & & $\mathrm{R}$ & & & & & & & & & & & & $\mathrm{R}$ & $\mathrm{F}$ & $\mathbf{R}$ \\
\hline & & $4 \mathrm{H}-3-114$ & G & C & $\mathrm{R}$ & $\mathrm{R}$ & & & & & $\mathrm{R}$ & & & & & & & & & & $\mathrm{R}$ & $\mathrm{A}$ & $\mathrm{R}$ \\
\hline & & $4 \mathrm{H}-4-23$ & $\mathrm{M}$ & C & $\mathrm{F}$ & $\mathrm{R}$ & & & $\mathrm{R}$ & & & & & & & & & & & & $\mathrm{R}$ & $\mathrm{C}$ & $\mathrm{R}$ \\
\hline & & $4 \mathrm{H}-5-18$ & $\mathrm{M}$ & C & $\mathrm{R}$ & $\mathrm{R}$ & & & $\mathrm{R}$ & & & & & & & & & & & & $\mathrm{R}$ & $\mathrm{A}$ & \\
\hline & & $4 \mathrm{H}-6-18$ & M & C & $\mathrm{R}$ & $\mathrm{R}$ & & & $\mathrm{R}$ & & & & & & & & & & & & & $\mathrm{F}$ & F \\
\hline & & $4 \mathrm{H}-\mathrm{CC}$ & G & A & K & & & & $\mathrm{F}$ & & & & & & & & & & & & & $\mathrm{C}$ & $\mathrm{F}$ \\
\hline & & $5 \mathrm{H}-1-87$ & $\mathrm{M}$ & $\mathrm{A}$ & $\mathrm{E}$ & & & & $\mathrm{R}$ & & & & & & & & & & & & & $\mathrm{C}$ & $\mathrm{R}$ \\
\hline & & $5 \mathrm{H}-2-72$ & G & A & $\mathrm{E}$ & & & & $\mathrm{R}$ & & $\mathrm{R}$ & & & & & & & & & & $\mathrm{R}$ & $\mathrm{F}$ & $\mathrm{R}$ \\
\hline & & $5 \mathrm{H}-3-86$ & $\mathrm{M}$ & C & $\mathrm{R}$ & & & & $\mathrm{R}$ & & & & & & & & & & & & & $\mathrm{F}$ & \\
\hline & & $5 \mathrm{H}-4-83$ & M & $\mathrm{F}$ & & & & & $\mathrm{R}$ & & & & & & & & & & & & & $\mathrm{F}$ & \\
\hline & $\mathrm{CN} 13 \mathrm{~b}$ & $5 \mathrm{H}-5-70$ & G & C & & & & & $\mathrm{R}$ & & & & & & & & & & & & $\mathrm{R}$ & $\mathrm{C}$ & \\
\hline & & $5 \mathrm{H}-6-54$ & G & C & $\mathrm{F}$ & $\mathrm{R}$ & & & $\mathrm{F}$ & & $\mathrm{R}$ & & & & & & & & & & & $\mathrm{F}$ & \\
\hline & & $5 \mathrm{H}-\mathrm{CC}$ & G & C & $\mathrm{F}$ & $\mathrm{R}$ & & & $\mathrm{F}$ & & & & & & & & & & & & & & \\
\hline & & $6 \mathrm{H}-1-121$ & G & F & $\mathrm{R}$ & & & & $\mathrm{R}$ & & & & & & & & & & & & $\mathrm{R}$ & & \\
\hline & $\mathrm{CN} 13 \mathrm{a}$ & $6 \mathrm{H}-2-121$ & $\mathrm{G}$ & A & $\mathrm{F}$ & $\mathrm{R}$ & & & $\mathrm{F}$ & & & & & & & & & & & & & & $F$ \\
\hline & & $6 \mathrm{H}-3-121$ & G & C & $\mathrm{C}$ & $\mathrm{R}$ & & & $\mathrm{F}$ & & & & & & & & & & & & & & $\mathrm{R}$ \\
\hline & & $6 \mathrm{H}-4-12 \mathrm{I}$ & G & $\mathrm{F}$ & $\mathrm{F}$ & $\mathrm{R}$ & & & $\mathrm{F}$ & & & & $\mathrm{R}$ & & & & & & & & & $\mathrm{R}$ & R \\
\hline & & $6 \mathrm{H}-5-77$ & $\mathrm{P}$ & C & $\mathrm{F}$ & & & & $\mathrm{R}$ & & & & $\mathrm{R}$ & & & & & & $\mathrm{R}$ & & & $\mathrm{R}$ & $\mathrm{F}$ \\
\hline & & $6 \mathrm{H}-6-139$ & $\mathrm{M}$ & C & $\mathrm{F}$ & $\mathrm{R}$ & & & $\mathrm{F}$ & & & & $\mathrm{R}$ & & & & & & $\mathrm{R}$ & & & $\mathrm{R}$ & $\mathrm{F}$ \\
\hline & & $6 \mathrm{H}-\mathrm{CC}$ & G & C & $\mathrm{F}$ & $\mathrm{R}$ & & & $\mathrm{F}$ & & $\mathrm{R}$ & & $\mathrm{R}$ & & & & & & $\mathrm{R}$ & & & $\mathrm{R}$ & F \\
\hline & $\mathrm{CN} 12 \mathrm{~d}$ & $7 \mathrm{H}-1-12$ & $\mathrm{P}$ & $\mathrm{F}$ & $\mathrm{R}$ & $\mathrm{R}$ & & & $\mathrm{R}$ & & & & $\mathrm{R}$ & & & & & & $\mathrm{R}$ & & & & R \\
\hline & & $7 \mathrm{H}-2-12$ & $\mathrm{M}$ & $\mathrm{F}$ & $\mathrm{F}$ & $\mathrm{R}$ & & & R & & & & $\mathrm{R}$ & & & & & & & & & & $\mathrm{R}$ \\
\hline & & $7 \mathrm{H}-3-12$ & $\mathrm{M}$ & C & $\mathrm{R}$ & & & & $\hat{R}$ & & & & $\mathrm{R}$ & & & & & & & & & $\mathrm{R}$ & $\mathrm{R}$ \\
\hline & & $7 \mathrm{H}-4-12$ & G & C & $\mathrm{F}$ & $\mathrm{R}$ & & & $\mathrm{F}$ & & & & $\mathrm{R}$ & & & & & & $\mathrm{R}$ & & & $\mathrm{R}$ & $\mathrm{F}$ \\
\hline & & $7 \mathrm{H}-5-12$ & $\mathrm{M}$ & C & $\mathrm{R}$ & $\mathrm{R}$ & & & $\mathrm{F}$ & & $\mathrm{R}$ & & $\mathrm{R}$ & & & & & & $\mathrm{R}$ & & & $\mathrm{R}$ & $\mathrm{R}$ \\
\hline & & $7 \mathrm{H}-6-12$ & G & $\mathrm{F}$ & $\mathrm{F}$ & $\mathrm{R}$ & & & $\mathrm{F}$ & & & & $\mathrm{R}$ & $\mathrm{R}$ & & & & & $\mathrm{R}$ & & & $\mathrm{R}$ & $\mathrm{R}$ \\
\hline & & 7H-CC & M & F & $\mathrm{F}$ & $\mathbf{R}$ & & & $\mathrm{F}$ & & $\mathrm{R}$ & & $\mathrm{R}$ & $\mathbf{R}$ & & & & & $\mathrm{R}$ & & & $\mathrm{R}$ & R \\
\hline & $\mathrm{CN} 12 \mathrm{~s}$ & $8 \mathrm{H}-1-14$ & $\mathrm{P}$ & $\mathrm{F}$ & $\mathrm{F}$ & $\mathrm{R}$ & & & $\mathrm{F}$ & & & & $\mathrm{R}$ & $\mathrm{R}$ & & & & & $\mathrm{R}$ & & & $\mathrm{R}$ & $\mathrm{R}$ \\
\hline & $\mathrm{CN} 12 \mathrm{c}$ & $8 \mathrm{H}-2-14$ & $P$ & $\mathrm{~F}$ & $\mathrm{R}$ & & & & $\mathrm{F}$ & & & & $\mathrm{R}$ & $\mathrm{R}$ & & & & & & & & $\mathrm{R}$ & $\mathrm{R}$ \\
\hline late & & $8 \mathrm{H}-3-14$ & G & $\mathrm{F}$ & $\mathrm{R}$ & $\mathbf{R}$ & & & $\mathrm{F}$ & $\mathrm{R}$ & $\mathrm{R}$ & & $\mathrm{R}$ & $\mathrm{R}$ & & & & & & & & $\mathrm{R}$ & $\mathrm{F}$ \\
\hline Pliocene & & $8 \mathrm{H}-4-14$ & M & C & $\mathrm{F}$ & $\mathrm{R}$ & & & $\mathrm{F}$ & $\mathrm{R}$ & $\mathrm{R}$ & & $\mathrm{R}$ & $\mathrm{R}$ & & & & & $\mathrm{R}$ & & & & R \\
\hline & & $8 \mathrm{H}-5-14$ & G & C & $\mathrm{F}$ & & & & $\mathrm{F}$ & & $\mathrm{R}$ & & $\mathrm{R}$ & $\mathrm{R}$ & & $\mathrm{R}$ & & & & & & $\mathrm{R}$ & R \\
\hline & & $8 \mathrm{H}-6-14$ & M & C & $\mathrm{F}$ & $\mathrm{R}$ & $\mathrm{R}$ & & C & & & & $\mathrm{R}$ & $\mathrm{R}$ & & $\mathrm{R}$ & & & $\mathrm{R}$ & & & $\mathrm{R}$ & $\mathrm{R}$ \\
\hline & $\mathrm{CN} / 2 \mathrm{~b}$ & $8 \mathrm{H}-\mathrm{CC}$ & M & C & $\mathrm{F}$ & $\mathrm{R}$ & $\mathrm{R}$ & & C & & & $\mathbf{R}$ & $\mathrm{R}$ & $\mathrm{R}$ & & $\mathbf{R}$ & & & $\mathrm{R}$ & & & $\mathrm{R}$ & R \\
\hline & & $9 \mathrm{H}-1-47$ & $\mathrm{P}$ & $\mathrm{F}$ & $\mathrm{F}$ & $\mathrm{R}$ & $\mathrm{R}$ & & $\mathrm{F}$ & & & & $\mathrm{R}$ & $\mathrm{F}$ & & $\mathrm{F}$ & & & $\mathrm{R}$ & & & $\mathrm{R}$ & $\mathrm{R}$ \\
\hline & & $9 \mathrm{H}-2-57$ & M & F & $\mathrm{R}$ & $\mathrm{R}$ & $\mathrm{R}$ & & $\mathrm{F}$ & & $\mathrm{R}$ & & $\mathrm{R}$ & $\mathrm{F}$ & $\mathrm{R}$ & $\mathrm{F}$ & & $\mathrm{R}$ & & & & $\mathrm{R}$ & $\mathrm{R}$ \\
\hline & & $9 \mathrm{H}-3-96$ & $\mathrm{M}$ & F & $\mathrm{F}$ & $\mathrm{R}$ & $\mathrm{R}$ & & $\mathrm{R}$ & & $\mathrm{R}$ & & $\mathrm{R}$ & $\mathrm{F}$ & $\mathrm{R}$ & $\mathrm{F}$ & & $\mathrm{R}$ & $\mathrm{R}$ & & & $\mathrm{R}$ & R \\
\hline & & $9 \mathrm{H}-4-53$ & M & C & C & $\mathrm{R}$ & $\mathrm{R}$ & & $\mathrm{R}$ & & $\mathrm{R}$ & $\mathbf{R}$ & $\mathrm{R}$ & $\mathrm{F}$ & $\mathrm{R}$ & $\mathrm{R}$ & & $\mathrm{R}$ & & & & $\mathrm{R}$ & $\mathrm{R}$ \\
\hline & & $9 \mathrm{H}-5-55$ & M & A & C & $\mathrm{R}$ & $\mathrm{R}$ & & $\mathrm{F}$ & & & $\mathrm{R}$ & $\mathrm{F}$ & $\mathrm{F}$ & $\mathrm{R}$ & $\mathrm{R}$ & & $\mathrm{R}$ & $\mathrm{R}$ & & & $\mathrm{R}$ & $\mathrm{F}$ \\
\hline & & $9 \mathrm{H}-6-56$ & G & A & C & $\mathrm{R}$ & $\mathrm{R}$ & & $\mathrm{F}$ & & & $\mathrm{R}$ & $\mathrm{F}$ & $\mathrm{F}$ & & $\mathbf{R}$ & & $\mathrm{R}$ & & $\mathrm{R}$ & & $\mathrm{R}$ & $\mathrm{F}$ \\
\hline & & $9 \mathrm{H}-7-19$ & M & C & C & $\mathrm{R}$ & $\mathrm{R}$ & & C & & $\mathrm{R}$ & $\mathrm{R}$ & $\mathrm{R}$ & $\mathrm{F}$ & & $\mathrm{R}$ & & $\mathrm{R}$ & & & & $\mathrm{R}$ & $\mathrm{F}$ \\
\hline & & 9H-CC & G & C & C & $\mathrm{R}$ & $\mathrm{R}$ & & C & & & $\mathrm{R}$ & $\mathrm{R}$ & $\mathrm{F}$ & & $\mathrm{R}$ & & $\mathrm{R}$ & $\mathrm{R}$ & $\mathrm{R}$ & & $\mathrm{R}$ & R \\
\hline & & $10 X-1-132$ & G & $\mathrm{A}$ & $\mathrm{F}$ & $\mathrm{R}$ & & & C & & & $\ddot{R}$ & $\mathrm{R}$ & $\mathrm{F}$ & & $\mathrm{R}$ & & $\mathrm{R}$ & & $\mathrm{R}$ & & $\mathrm{R}$ & $\mathrm{F}$ \\
\hline & $\mathrm{CN} 12 \mathrm{a}$ & $10 X-2-52$ & M & C & $\mathrm{F}$ & $\mathrm{R}$ & $\mathrm{R}$ & & $\mathrm{R}$ & & & $\mathrm{R}$ & $\widehat{R}$ & $\mathrm{~F}$ & & $\mathrm{R}$ & & $\mathrm{R}$ & $\mathrm{R}$ & $\mathrm{R}$ & & $\mathrm{R}$ & R \\
\hline & & $10 \mathrm{X}-\mathrm{CC}$ & M & C & $\mathrm{F}$ & & & & $\mathrm{F}$ & & & $\mathrm{R}$ & $\mathrm{R}$ & $\mathrm{F}$ & & $\mathrm{R}$ & & $\mathrm{R}$ & $\mathrm{R}$ & $\mathrm{R}$ & & $\mathrm{F}$ & F \\
\hline & & $11 X-1-39$ & $\mathrm{M}$ & C & $\mathrm{F}$ & $\mathbf{R}$ & & & C & & $\mathrm{R}$ & $\mathrm{R}$ & $\mathrm{R}$ & $\mathrm{F}$ & & $\mathrm{R}$ & & $\mathrm{R}$ & & $\mathrm{R}$ & & $\mathrm{R}$ & $\mathrm{F}$ \\
\hline & & $11 X-2-91$ & G & C & $\mathrm{R}$ & $\mathrm{R}$ & & & C & & $\mathrm{R}$ & $\mathrm{R}$ & $F$ & $\mathrm{~F}$ & & $\mathrm{~F}$ & & $\mathrm{R}$ & $\mathrm{R}$ & $\mathrm{R}$ & & $\mathrm{R}$ & R \\
\hline & & $11 X-3-39$ & $\mathrm{M}$ & A & C & $\mathrm{R}$ & & & $\mathrm{F}$ & & & $\mathrm{R}$ & $\mathrm{R}$ & $\mathrm{F}$ & & $\mathrm{F}$ & & $\widehat{R}$ & $\mathrm{R}$ & $\mathrm{R}$ & & $\mathrm{R}$ & R \\
\hline & & $11 \mathrm{X}-\mathrm{CC}$ & $\mathrm{M}$ & C & F & $\mathrm{R}$ & & & $\mathrm{F}$ & & & $\mathrm{R}$ & $\mathrm{F}$ & $\mathrm{F}$ & & $\mathrm{R}$ & & $\mathrm{R}$ & $\mathrm{R}$ & $\mathrm{R}$ & & $\mathrm{R}$ & R \\
\hline & & $12 X-1-84$ & G & A & C & $\mathrm{R}$ & & & $\mathrm{R}$ & & $\mathrm{R}$ & $\mathrm{R}$ & $\mathrm{F}$ & C & $\mathrm{R}$ & $\mathbf{R}$ & & $\mathrm{R}$ & $\mathrm{R}$ & $\mathrm{R}$ & & $\mathrm{R}$ & $\mathrm{R}$ \\
\hline & & $12 X-2-62$ & $\mathrm{P}$ & C & $\mathrm{F}$ & $\mathrm{R}$ & & & $\mathrm{R}$ & & & $\mathrm{R}$ & $\mathrm{F}$ & $\mathrm{F}$ & $\mathrm{R}$ & $\mathrm{R}$ & & $\mathrm{R}$ & $\mathrm{R}$ & $\mathrm{R}$ & & $\mathrm{F}$ & R \\
\hline
\end{tabular}

${ }^{\text {a }}$ See list in Table 1 for identification of species. 
Table 3 (continued).

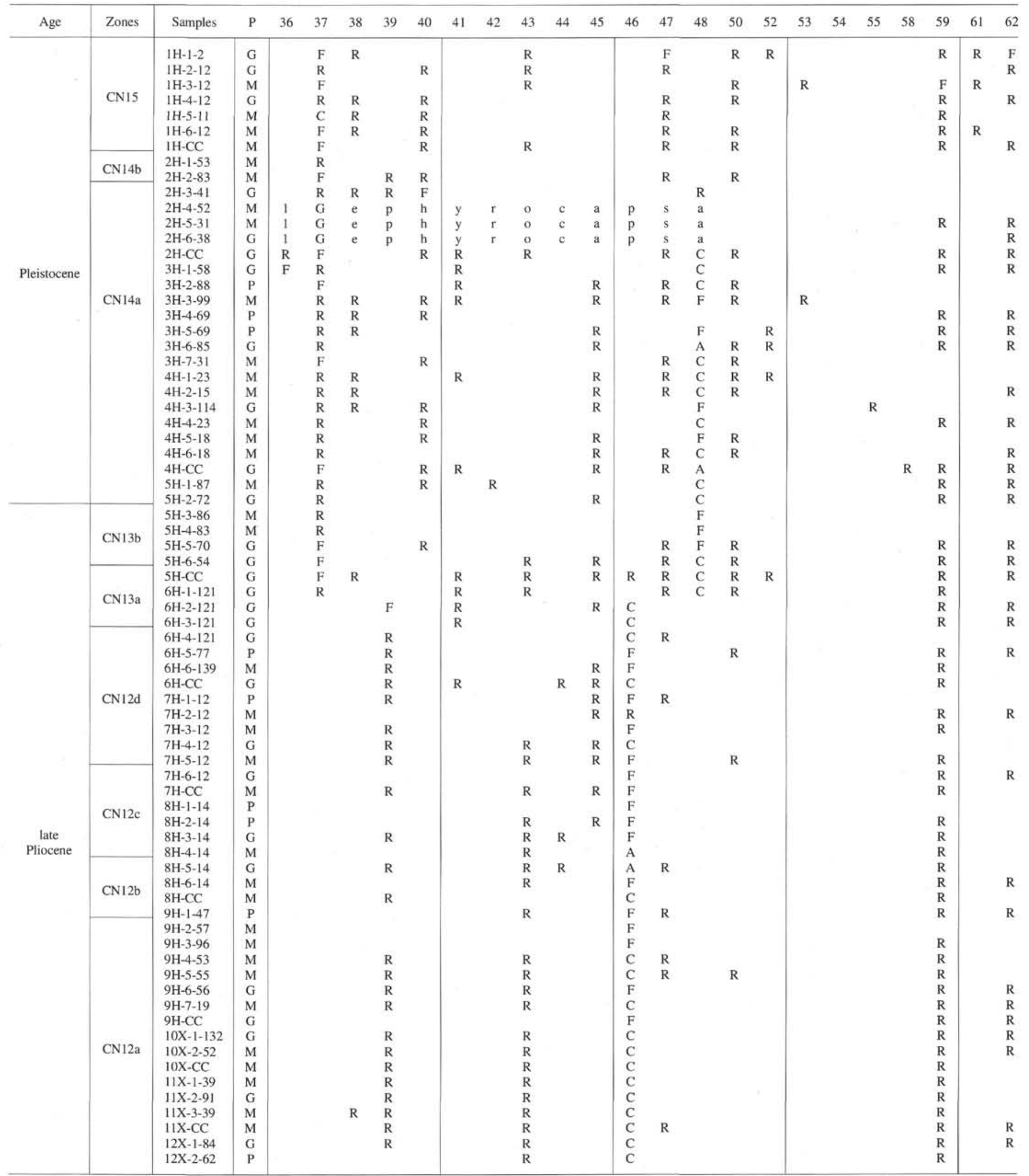


Table 4. Calcareous nannofossil distribution at Hole 785A. ${ }^{\mathrm{a}}$

\begin{tabular}{|c|c|c|c|c|c|c|c|c|c|c|c|c|c|c|c|c|c|c|c|c|c|c|c|c|}
\hline Age & Zones & Samples & $\mathrm{P}$ & 6 & 7 & 10 & 14 & 32 & 34 & 35 & 37 & 38 & 39 & 40 & 41 & 45 & 46 & 47 & 48 & 50 & 52 & 58 & 59 & 62 \\
\hline \multirow{11}{*}{ Pleistocene } & CN15 & $1 \mathrm{H}-1-145$ & M & & & $\mathrm{R}$ & $\mathrm{R}$ & F & $\mathrm{F}$ & $\mathrm{F}$ & $\mathrm{R}$ & & & $\mathrm{R}$ & & & & $\mathrm{R}$ & & $\mathrm{R}$ & & & $\mathrm{R}$ & \\
\hline & $\mathrm{CN} 14 \mathrm{~b}$ & $1 \mathrm{H}-2-2$ & M & $\mathrm{F}$ & & & $\mathrm{F}$ & & $\mathrm{F}$ & $\mathrm{F}$ & $\mathrm{F}$ & & $\mathrm{R}$ & $\mathrm{R}$ & & & $\mathrm{R}$ & $\mathrm{R}$ & & $\mathbf{R}$ & $\mathbf{R}$ & $\mathbf{R}$ & $\mathrm{R}$ & \\
\hline & $\mathrm{CN} 140$ & $1 \mathrm{H}-4-100$ & $\mathrm{P}$ & $\mathrm{R}$ & & & $\mathrm{R}$ & & $\mathrm{R}$ & $\mathrm{R}$ & $\mathrm{R}$ & & & & & & & $\mathrm{R}$ & & & & & & \\
\hline & \multirow{8}{*}{$\mathrm{CN} 14 \mathrm{a}$} & $1 \mathrm{H}-6-45$ & $\mathrm{P}$ & $\mathrm{R}$ & & & & & $\mathrm{R}$ & $\mathrm{R}$ & & & & & & & & & $\mathrm{R}$ & & & & & \\
\hline & & $2 \mathrm{H}-2-84$ & $M$ & $\mathrm{R}$ & & & $\mathrm{F}$ & & $\mathrm{F}$ & $\mathrm{F}$ & $\mathrm{R}$ & $\mathrm{R}$ & $R$ & $R$ & & & & $\mathrm{R}$ & $\mathrm{R}$ & $\mathrm{R}$ & & & $\mathrm{R}$ & \\
\hline & & $2 \mathrm{H}-5-84$ & G & $\mathrm{F}$ & $\mathrm{R}$ & $\mathrm{R}$ & & & $\mathrm{A}$ & C & $\mathrm{R}$ & & & & $\mathrm{R}$ & & & & & & & & & \\
\hline & & $2 \mathrm{H}-6-11$ & G & $\mathrm{F}$ & & R & $\mathrm{R}$ & & $\mathrm{A}$ & $\mathrm{F}$ & $\mathrm{R}$ & & & & $\mathrm{R}$ & & & $\mathrm{R}$ & $\mathrm{R}$ & & & & & \\
\hline & & $2 \mathrm{H}-\mathrm{CC}$ & G & $\mathrm{F}$ & $\mathrm{R}$ & & & & $\mathrm{R}$ & $\mathrm{R}$ & $\mathrm{R}$ & & & & $\mathrm{R}$ & $\mathrm{R}$ & & $\mathrm{R}$ & & & & & & \\
\hline & & $5 \mathrm{H}-\mathrm{CC}$ & G & C & $\mathrm{R}$ & & $\mathrm{R}$ & & & C & $\mathrm{R}$ & & & $\mathrm{R}$ & & & & & $\mathrm{C}$ & & & & R & $\mathrm{R}$ \\
\hline & & $6 \mathrm{H}-\mathrm{CC}$ & M & $\mathrm{F}$ & $\mathrm{R}$ & & $\mathrm{R}$ & & $\mathrm{R}$ & $\mathrm{R}$ & $\mathrm{R}$ & & & & & $\mathbf{R}$ & $\mathrm{R}$ & $\mathrm{F}$ & $\mathrm{A}$ & $\mathrm{R}$ & $\mathrm{R}$ & & $\mathbf{R}$ & $\mathrm{R}$ \\
\hline & & 7H-CC & G & $\mathrm{F}$ & $\mathrm{R}$ & $\mathrm{R}$ & & & $\mathrm{C}$ & $\mathrm{R}$ & $\mathrm{R}$ & $\mathrm{R}$ & & & $\mathrm{R}$ & $\mathrm{R}$ & & $\mathrm{F}$ & A & $\mathrm{F}$ & & & $\mathrm{R}$ & $\mathrm{R}$ \\
\hline
\end{tabular}

${ }^{a}$ See list in Table 1 for identification of species.

Table 5. Distribution of calcareous nannofossils at Hole $786 \mathrm{~A}$ in the latest Miocene-late Pleistocene. $^{\text {a }}$

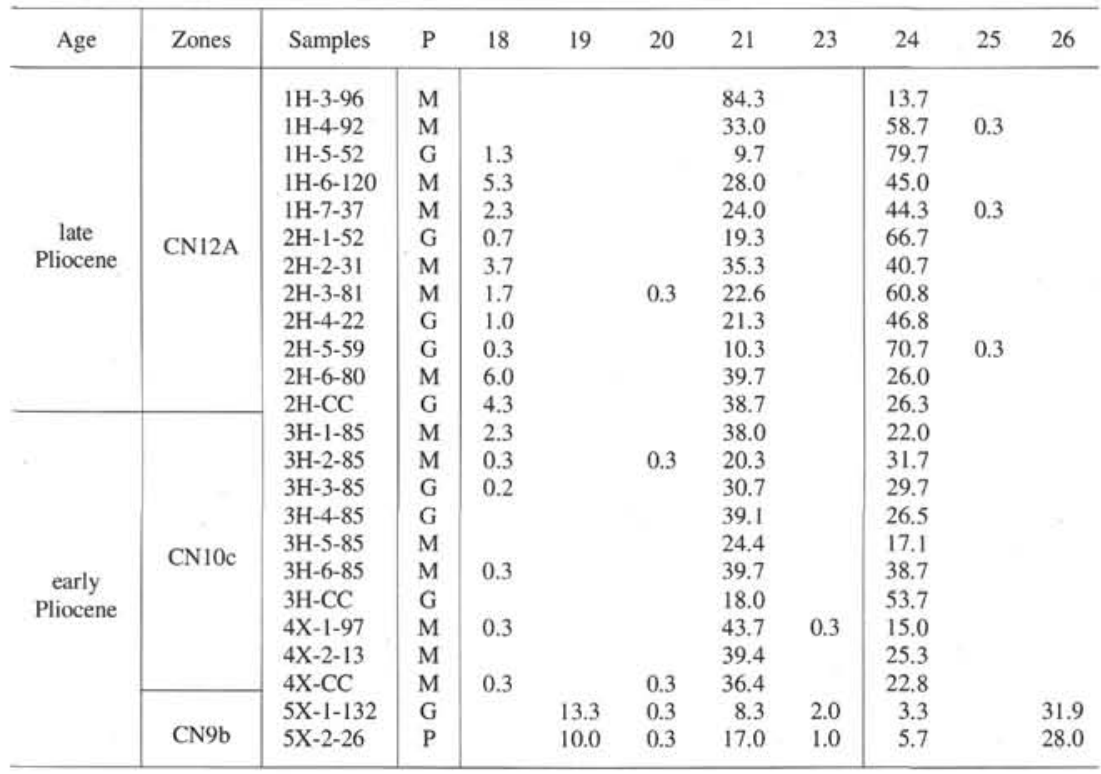

${ }^{a}$ See list in Table 1 for identification of species.

Subzone CN10b. Berggren et al. (1985) agreed that 5.6 Ma was the contemporaneous LAD of $A$. amplificus, $D$. berggrenii, and $D$. quinqueramus. Thus, the sequence and the absolute ages of the extinctions of these taxa are not yet clear.

The last occurrence of Amaurolithus tricorniculatus predates, in both holes, the LAD of $A$. delicatus and A. primus, that is contemporaneous in Hole 786A (condensed sequence), while at Hole 782A the $A$. primus LAD predates the $A$. delicatus last occurrence. But the three events are very near each other.

Amaurolithus amplificus and A. primus have a small acme, the former just after its FAD and the latter at the base of Subzone CN10b. Amaurolithus delicatus has its acme, which corresponds also to the $A$. tricorniculatus acme, in the lower half of Subzone CN10c and another minor peak at the top of Subzone CN1Ob (Fig. 4). The older of these events corresponds to the dramatic decreases in Coccolithus pelagicus, Dictyococcites aff. $D$. antarcticus, and Discoaster variabilis and to an increase in Discoaster brouweri, D. pentaradiatus, and especially $D$. surculus. The highest peak, corresponding to another increase in Discoaster pentaradiatus and D. surculus, and is contemporaneous to the reestablishment of the Reticulofenestra pseudoumbilicus dominance.

In Sample 125-782A-15X-1, 5-6 cm, the only specimen of Amaurolithus bizzarrus was found. Before its extinction, A. delicatus shows another minor peak, toward the top of Subzone $\mathrm{CN} 10 \mathrm{c}$ as observed also by Muller (1990) in the Mediterranean area. The contemporaneous $A$. delicatus/A. tricorniculatus acme within Subzone $\mathrm{CN} 10 \mathrm{c}$ and the other described bioevents were also detected at Hole 786A.

The preference of ceratoliths to warm water is confirmed by their strong decrease in correlation to the cooling events of the latest Miocene and at 3.2 and $2.4 \mathrm{Ma}$.

The genus Ceratolithus is represented at the beginning of the early Pliocene by rare specimens of $C$. acutus, C. armatus, and C. rugosus. After the appearance of $C$. cristatus, within Subzone CN10c, the genus becomes more frequent. $C$. separatus has its first appearance within Subzone CN12a and becomes extinct at the top of CN12b at Hole 782A, and at the top and within Subzone CN12a at Holes 786A and $781 \mathrm{~A}$, respectively. At these sites, however, there are some problems of reworking at the $\mathrm{CN} 12 \mathrm{a} / \mathrm{CN} 12 \mathrm{~b}$ boundary (see discussion above). The acmes of $C$. separatus and $C$. cristatus are recorded below and above of the cold event at $2.4 \mathrm{Ma}$, respectively.

\section{Discoasters}

Discoasters are usually common through the latest Miocene to late Pliocene interval, especially at the low-latitude Hole 781A. In the late Pliocene section, however, a marked decline in abundance of the 


\section{G. CIAMPO}

$\begin{array}{llll}\text { D. Dentaradiatus } \% & \text { D. variabilis } \% & \text { D brouweri } \% & \text { D. surculus } \%\end{array}$

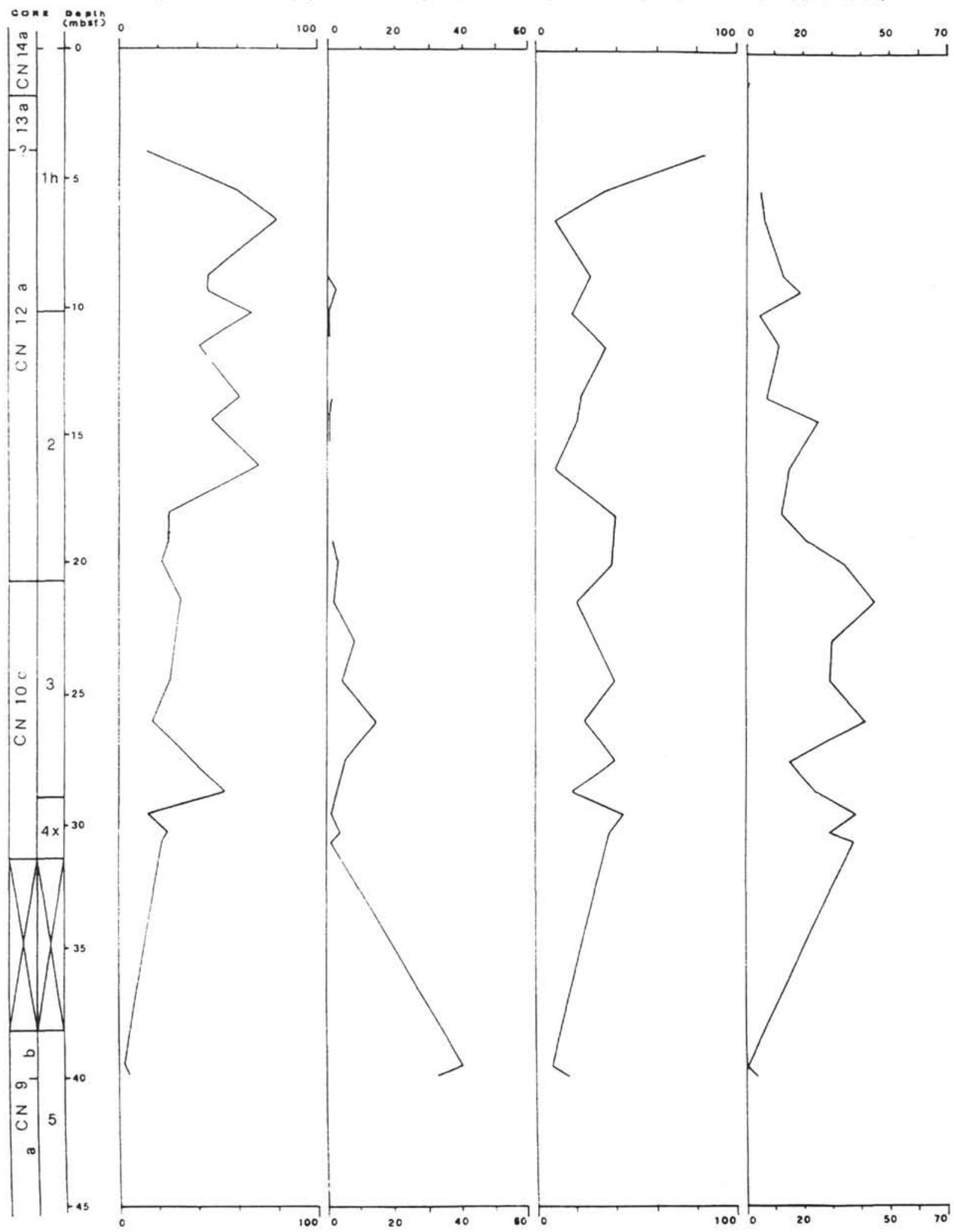

Figure 6. Percent of abundance of selected discoaster species at Hole 786A. Species percentage was calculated with respect to at least 300 specimens of the genus. Number of ceratoliths and Amaurolithus delicatus is with respect to 300 discoasters. 
A . asymmetricus $\%$

A. tamalis $\%$

Ceratolithus spp. $n / 300$

A. delicatus

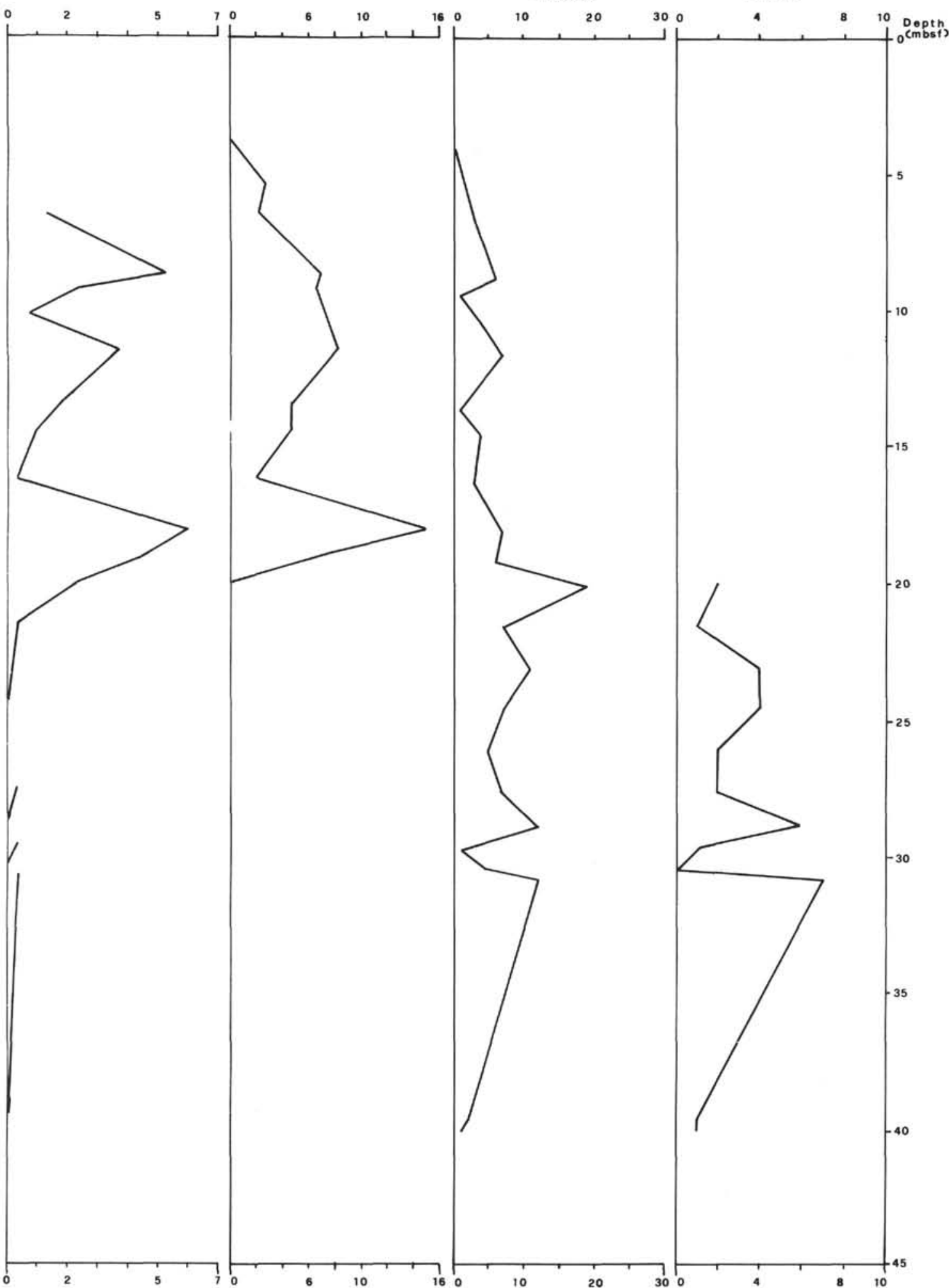

Figure 6 (continued). 


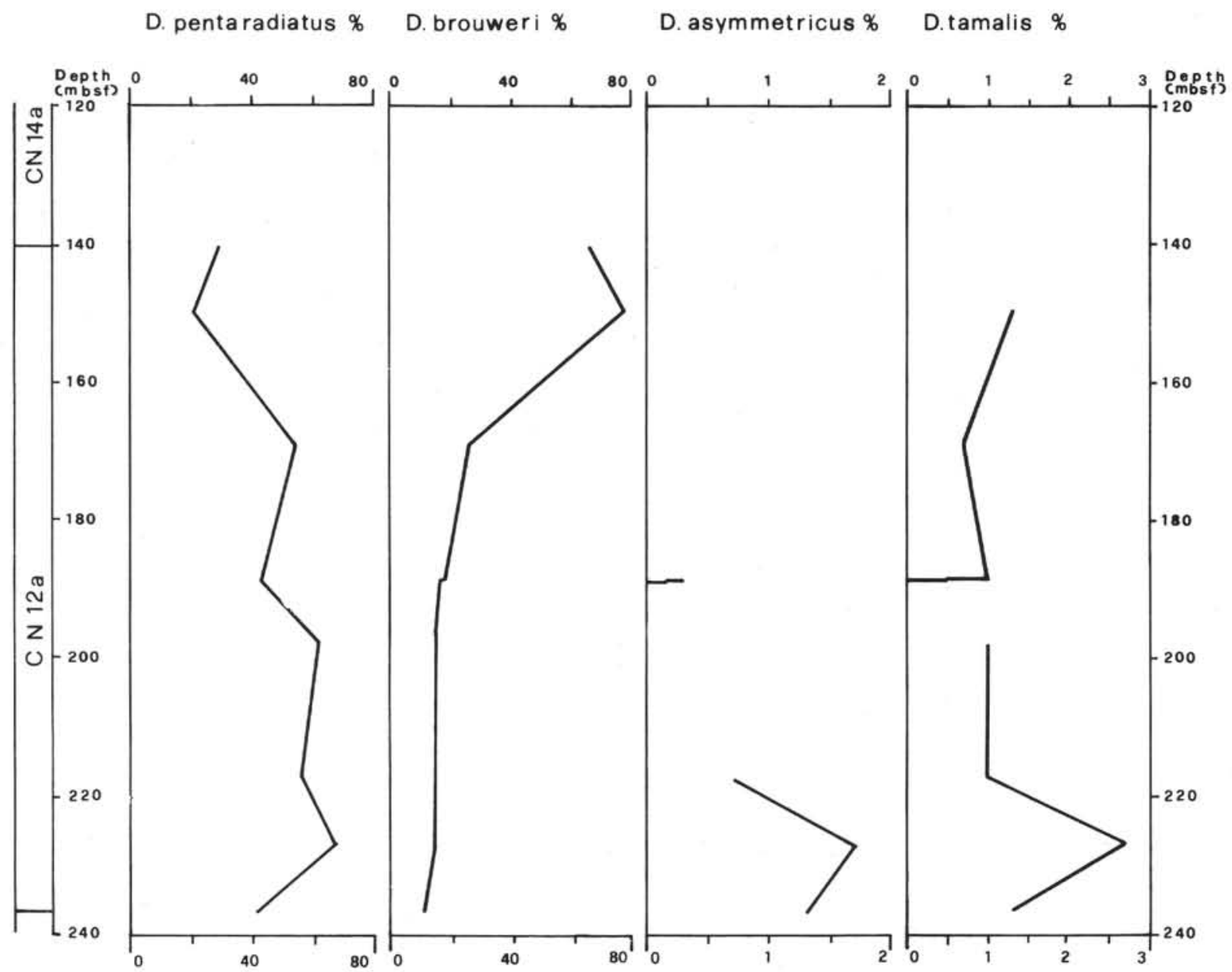

Figure 7. Percent of abundance of selected discoaster species at Hole 781A, evaluated by counting at least 300 specimens. within the genus.

discoasters starts at the base of the cold event of $2.4 \mathrm{Ma}$. This decrease also affects the low-latitude assemblages. The event has been pointed out also in the Atlantic Ocean by Backman and Pestiaux (1987) and in the Mediterranean Basin (Muller, 1990; Rio et al., 1990).

\section{Discoaster variabilis}

The beginning of Subzone CN9b is characterized by the last episodes of dominance of Discoaster quinqueramus/D. berggrenii group. Immediately afterward Discoaster variabilis takes over among discoasters, and other species are subordinate, until the top of Subzone CN10b. At the CN10b/CN10c boundary, a change among discoasters is caused by the percentage collapse of $D$. variabilis, and the increase of D. brouweri, from $7 \%$ to $30 \%$. Within Subzone $\mathrm{CN} 10 \mathrm{~b}, D$. pentaradiatus ranges from $15 \%$ to $21 \%$, and D. surculus, from $9 \%$ to $43 \%$. These changes concern all the nannofossil associations and shortly afterward, the decreases in Coccolithus pelagicus and Dictyococcites aff. D. antarcticus and the increase in Calcidiscus leptoporus and Reticulofenestra pseudoumbilicus occur. These changes may be linked to warmer water conditions, starting from the early part of the early Pliocene (Thunell, 1979). Through the rest of the Pliocene, D. variabilis is subordinate to the other discoasters. This species displays only two peaks near each other, in the middle and toward the end of Subzone CN10c.The first of the two peaks is very distinctive. The last occurrence of $D$. variabilis lies in the lower half of Subzone CN12a at Hole 782A, where reworking was not observed. Backman and Shackleton (1983) reported a similar trend of $D$. variabilis from Core V28-179 (Central Equatorial Pacific).

\section{Discoaster brouweri, D. pentaradiatus, and D. surculus}

They are the most common discoasters throughout the Pliocene section. They display different trends, linked probably to their different climatic preferences. Discoaster brouweri shows a cyclic abundance pattern (Fig. 5), with three wider cycles of about 0.8 m.y., each consisting of smaller cycles. The longer cycles broadly correspond to decreases in the ceratoliths and in Discoaster surculus, and seem to have a cold/temperate or a temperate significance. The first occurs at the bottom of Subzone CN10c, before the reestablishment of the dominance of Reticulofenestra pseudoumbilicus. The sharp end of this cycle corresponds to the Amaurolithus delicatus/A. tricorniculatus acme. The second cycle summit encompasses Subzone $\mathrm{CN} 11 \mathrm{~b}$, where the Discoaster asymmetricus and the D. tamalis acme occur; it is decreasing near the $3.2 \mathrm{Ma}$ cooling event. The third cycle includes the second half of Subzone CN12a, with a peak in Subzone $\mathrm{CN} 12 \mathrm{~b}$, where all discoasters become very rare. This third cycle shows a break at the $\mathrm{CN} 12 \mathrm{a} / \mathrm{CN} 12 \mathrm{~b}$ boundary, in correspondence with the Ceratolithus separatus acme. These cycles are clearly evident only at Hole $782 \mathrm{~A}$, where many samples are available. The beginning of the Discoaster brouweri domination at the top of Subzone $\mathrm{CN} 12 \mathrm{~b}$ is evident in all three sites.

At the low-latitude Hole 781A, D. brouweri is represented by much lower percentages among discoasters than at the middle-latitude Holes 782A and 786A. Even if it had been based on a different method, the abundance curve of Discoaster brouweri in Core V28179 (Backman and Shackleton, 1983) is similar, especially through the Gauss Chron. 
The Discoaster surculus trend, on the contrary, parallels that of the ceratoliths. This taxon, very rare in Subzone CN9b, increases through the early Pliocene and dominates among discoasters in the second half of Subzone CN10c. Then, it decreases through Subzones $\mathrm{CN} 11 \mathrm{~b}$ and $\mathrm{CN} 12 \mathrm{a}$ and, just before its extinction at the top of Subzone $\mathrm{CN} 12 \mathrm{~b}$, has a last distinctive peak. These patterns are common to Holes 782A and 786A. At Hole 781A, it is usually more frequent. Discoaster surculus, like or even more than D. pentaradiatus, seems to be very sensitive to climatic changes (Tables 6-8).

In reality, it is difficult to interpret the features of the Discoaster pentaradiatus diagram, as its trend shows a continous increase through the Pliocene until its dramatic decrease at the top of Subzone $\mathrm{CN} 12 \mathrm{~b}$. As a whole, its pattern is of a warm-water species, decreasing at or near the cooling events, but often its minima merely correspond to Discoaster surculus maxima. A peculiar feature of Discoaster pentaradiatus is its domination in Subzones CN12a and CN12b. This bioevent is evident in all the three sites.

\section{Discoaster asymmetricus and Discoaster tamalis}

The contemporaneous acmes of D. asymmetricus and D. tamalis, are well-known global bioevents (Backman and Shackleton, 1983; Backman and Pestiaux, 1987; Rio et al., 1990). Here the Discoaster asymmetricus acme is considered to be the rock-interval within which the taxon is continuously recorded in the samples. This definition is not much different from that of Rio et al. (1990) in so far as it concerns middle-latitude Holes 782A and 786A. At the beginning of its continuous record, D. asymmetricus shows a percentage of $6 \%$, among discoasters, at both sites. At the low-latitude Hole 781A, where the acme event is also evident, the percentages are much lower. At Hole $782 \mathrm{~A}$, the beginning of the $D$. asymmetricus acme is contemporaneous to the FAD's of D. tamalis, D. decorus, and Pseudoemiliania lacunosa; in the Hole 786A, the beginning of the D. asymmetricus acme and the FAD of $P$. lacunosa slightly predate the FAD's of $D$. tamalis and $D$. decorus, but here, there are problems of reworking or of drilling disturbance. In all the holes the end of the D. asymmetricus acme lies just below the top of Subzone CN12a. The preference of cooler-water of D. asymmetricus and D. tamalis (Rio et al., 1990) is confirmed by their maxima near the 3.2-Ma cooling event and by the lower percentage ( $2 \%$ and $3 \%$, respectively) in the low-latitude sites.

\section{Reticulofenestra pseudoumbilicus}

This taxon characterizes the temperate assemblages (Lohman and Carlson, 1981). Usually, it dominates the associations in the interval (Subzones CN9b/CN1lb) in which the global quantitative analysis was performed. As discussed above, $R$. pseudoumbilicus presents three dramatic decreases: (1) within Subzone CN9b, (2) at its top, and (3) at the top of Subzone CN10c, not far from its LAD at the top of the short Zone CN11. The first is a short episode; the second episode of low $R$. pseudoumbilicus percentages, spreads from the top of Subzone CN9b to the early part of Subzone CN10c, only a secondary peak at the $\mathrm{CN} 10 \mathrm{~b} / \mathrm{CN} 10 \mathrm{c}$ boundary occurs.

The Dictyococcites aff. D. antarcticus curve seems to be complementary to the $R$. pseudoumbilicus curve, with the main peaks falling within Subzones CN9b and CN10b. Note that a similar feature can be observed in an early Pliocene land section, the Fiumara Capperano section, in Calabria (Italy) (Ciampo, unpubl. data), through Zones MPL1 and MPL2 (corresponding as a whole to Subzone $\mathrm{CN10b}$ ) (Fig. 8). Thus, this might be a global event, but further study will be required.

\section{TAXONOMIC NOTES}

Genus DICTYOCOCCITES Black, 1967

Dictyococcites aff. D. antarcticus, Haq 1976

(Pl. 1, Figs. 1, 2)

Dictyococcites antarcticus Haq, 1976, p. 561, pl. 3, figs. 1-5, 7, 8 .

Remarks. The species is similar to that species originally described by Haq in the structure of the central area (with a long furrow), and in size, 5-8 $\mu \mathrm{m}$. The difference is in the lower number of shield elements which are from 60 to 80 the Haq's species, and from 45 to 50 in Dictyococcites aff. D. antarcticus.

Occurrence. The taxon has been found from Subzone CN9b (late Miocene) until the lower part of Subzone CN10c (early Pliocene). It was also recorded in the early Pliocene of southern Italy.

\section{CONCLUSIONS}

The late Miocene to late Pleistocene sequences that were drilled in two areas $11^{\circ}$ of latitude apart provided interesting calcareous nannofossil assemblages. Nevertheless, some problems were encountered:

1. Carbonate dissolution. At some sites, the sediments were drilled close or below the CCD (783 and 784). In other cases, etching is linked to abundant volcanic ashes (Site 781) or to cooling events (Sites 782 and 786).

2. Poor recovery, which affected especially Site 781 , where only core catcher samples were often recovered, and the late Miocene/early Pliocene intervals of Sites 782 and 786. At these sites one found it impossible to recognize the Miocene/Pliocene boundary since several sections near the boundary were missing.

An unusually good correlation between biostratigraphic and magnetostratigraphic data (except within the early Pleistocene at Hole $782 \mathrm{~A}$ ) allowed for high stratigraphic resolution. This study is based on analysis of about 200 samples. A quantitative analysis was performed for about 100 samples. Sixty-two calcareous nannofossil species were recognized. Quantitative analysis allowed for finer biostratigraphic resolution and pointed out new events. Furthermore, it allowed the recognition of at least four cooling events: at $6.2 \mathrm{Ma}$, at the top of the late Miocene, and in the late Pliocene at 3.2 and 2.4 $\mathrm{Ma}$, on the basis of variations in composition of the assemblages. Some differences between middle- and low-latitude associations is pointed out.

\section{ACKNOWLEDGMENT}

I thank M. B. Cita for reviewing the manuscript. The careful and fine reviews of N. G. Marshall and of K. Perch-Nielsen are acknowledged. This work was supported by CNR grants.

\section{REFERENCES}

Backman, J., and Pestiaux, P., 1987. Pliocene Discoaster abundance variations, Deep Sea Drilling Project Site 606: biochronology and paleoenvironmental implications. In Ruddiman, W. F., Kidd, R. B., Thomas, E., et al., Init. Repts. DSDP, 94 (Pt. 2): Washington (U.S. Govt. Printing Office), 903-910.

Backman, J., and Shackleton, N. J., 1983. Quantitative biochronology of Pliocene and early Pleistocene calcareous nannofossils from the Atlantic, Indian, and Pacific oceans. Mar. Micropaleontol., 8:141-170. 
Table 6. Percent distribution of discoaster species at Hole 782A, calculated after counting 500 specimens of the genus. ${ }^{a}$

\begin{tabular}{|c|c|c|c|c|c|c|c|c|c|c|c|c|c|c|c|c|c|}
\hline Age & Zones & Samples & $\mathrm{P}$ & 18 & 19 & 20 & 21 & 22 & 23 & 24 & 25 & 26 & 27 & 28 & 29 & 30 & 31 \\
\hline \multirow{31}{*}{$\begin{array}{c}\text { late } \\
\text { Pliocene }\end{array}$} & $\mathrm{CN} 12 \mathrm{~d}$ & $7 \mathrm{H}-4-12$ & G & & & & 92.7 & & & & & & & & & 7.3 & \\
\hline & & $7 \mathrm{H}-5-12$ & $P$ & & & & 96.0 & & & & & & & & & 4.0 & \\
\hline & \multirow{6}{*}{$\mathrm{CN} 12 \mathrm{c}$} & $7 \mathrm{H}-6-12$ & G & & & & 97.3 & & & 1.3 & & & & & & 1.3 & \\
\hline & & $7 \mathrm{H}-\mathrm{CC}$ & $\mathrm{P}$ & & & & 98.3 & & & 0.3 & & & & & & 1.3 & \\
\hline & & $8 \mathrm{H}-1-14$ & $\mathrm{P}$ & & & & 99.0 & & & 0.3 & & & & & & 0.7 & \\
\hline & & $8 \mathrm{H}-2-14$ & $\mathrm{P}$ & & & & 99.0 & & & 1.0 & & & & & & & \\
\hline & & $8 \mathrm{H}-3-14$ & G & & & & 96.7 & & & 3.3 & & & & & & & \\
\hline & & $8 \mathrm{H}-4-14$ & $\mathrm{M}$ & & & & 89.3 & & & 9.0 & & & & & & 1.7 & \\
\hline & \multirow{4}{*}{$\mathrm{CN} 12 \mathrm{~b}$} & $8 \mathrm{H}-5-14$ & G & & & & 13.0 & & & 61.3 & & & & 25.7 & & & \\
\hline & & $8 \mathrm{H}-6-14$ & M & & & & 28.0 & & & 49.0 & & & & 22.7 & & 0.3 & \\
\hline & & $8 \mathrm{H}-\mathrm{CC}$ & M & 0.7 & & & 35.9 & & & 36.9 & & & & 26.2 & & 0.7 & \\
\hline & & $9 \mathrm{H}-1-47$ & $\mathrm{P}$ & & & & 16.6 & & & 28.7 & & & & 53.5 & & 1.3 & \\
\hline & \multirow{16}{*}{$\mathrm{CN} 12 \mathrm{a}$} & $9 \mathrm{H}-2-57$ & M & & & & 16.3 & & & 37.7 & 0.7 & & & 45.0 & 0.3 & & \\
\hline & & $9 \mathrm{H}-3-96$ & $\mathrm{M}$ & & & & 18.9 & & & 44.7 & 0.3 & & & 34.7 & 0.7 & 0.7 & \\
\hline & & $9 \mathrm{H}-4-53$ & M & 2.3 & & & 33.7 & & & 55.3 & 1.3 & & & 5.7 & 1.7 & & \\
\hline & & $9 \mathrm{H}-5-55$ & M & 4.7 & & & 27.7 & & & 42.0 & & & & 17.7 & 5.7 & & \\
\hline & & $9 \mathrm{H}-6-56$ & $\mathrm{G}$ & 6.0 & & & 31.0 & & & 35.3 & 0.3 & & & 20.7 & 5.7 & & 1.0 \\
\hline & & $9 \mathrm{H}-7-19$ & $\mathrm{M}$ & 2.0 & & & 24.0 & & & 55.3 & & & & 13.7 & 5.0 & & \\
\hline & & $9 \mathrm{H}-\mathrm{CC}$ & G & 3.0 & & & 27.3 & & & 55.7 & & & & 10.7 & 2.7 & 0.3 & 0.3 \\
\hline & & $10 X-1-132$ & G & 5.7 & & & 17.3 & & & 56.0 & & & & 13.0 & 7.0 & & 1.0 \\
\hline & & $10 \times-2-52$ & $\mathrm{M}$ & 4.3 & & & 15.0 & & & 52.0 & & & & 18.7 & 7.0 & 2.0 & 1.0 \\
\hline & & $10 \mathrm{X}-\mathrm{CC}$ & $\mathrm{M}$ & 2.7 & & & 10.7 & & & 61.7 & & & & 15.3 & 8.3 & 0.7 & 0.7 \\
\hline & & $11 X-1-39$ & $\mathrm{M}$ & & & & 15.9 & & & 51.2 & & & & 24.2 & 5.0 & & 3.0 \\
\hline & & $11 X-2-91$ & G & 8.0 & & & 36.3 & & & 21.7 & & & & 17.3 & 13.7 & 1.7 & 1.3 \\
\hline & & $11 X-3-39$ & $\mathrm{M}$ & 3.7 & & & 19.0 & & & 42.0 & & & & 24.7 & 3.7 & 0.7 & 6.3 \\
\hline & & $11 \mathrm{X}-\mathrm{CC}$ & M & 9.3 & & & 29.0 & & & 45.3 & & & & 7.3 & 7.0 & 0.7 & 1.3 \\
\hline & & $12 X-1-84$ & $\mathrm{G}$ & 5.0 & & & 30.7 & & & 33.7 & 0.3 & & & 20.0 & 6.7 & 1.3 & 2.3 \\
\hline & & $12 X-2-62$ & $\mathrm{P}$ & 7.0 & & & 39.0 & & & 26.3 & 0.3 & & & 20.3 & 2.7 & 0.3 & 4.0 \\
\hline & \multirow{3}{*}{ CNIIb } & $12 X-3-82$ & $G$ & 5.3 & & & 25.9 & & & 35.6 & & & & 21.3 & 2.7 & 1.0 & 8.3 \\
\hline & & $12 X-4-7$ & G & 6.0 & & & 31.0 & & & 15.3 & & & & 42.7 & 1.0 & 2.0 & 2.0 \\
\hline & & $12 \mathrm{X}-\mathrm{CC}$ & $\mathrm{M}$ & 6.0 & & 0.3 & 30.3 & & & 23.3 & & & & 27.3 & 5.3 & 0.7 & 6.7 \\
\hline & & $13 X-1-108$ & $\mathrm{M}$ & & & & 17.7 & & & 48.3 & & & & 30.0 & & & 4.0 \\
\hline & & $13 X-2-42$ & $\mathrm{G}$ & & & & 15.3 & & & 36.0 & & & & 31.7 & & & 17.0 \\
\hline & & $13 X-3-92$ & G & & & & 18.6 & & & 30.4 & 1.0 & & & 38.6 & & 0.3 & 11.1 \\
\hline & & $13 X-4-28$ & $\mathrm{P}$ & 0.3 & & & 17.9 & & & 25.3 & 0.7 & & & 39.9 & & & 16.0 \\
\hline & & $13 \mathrm{X}-\mathrm{CC}$ & G & & & & 10.6 & & & 37.2 & & & & 37.5 & & & 14.6 \\
\hline & & $14 X-1-82$ & $P$ & 0.7 & & & 16.0 & & & 16.7 & & & & 63.0 & & 0.3 & 3.3 \\
\hline & & $14 X-2-62$ & M & & & & 9.7 & & & 22.7 & & & & 44.3 & & & 23.3 \\
\hline & & $14 X-3-112$ & $\mathrm{G}$ & & & & 17.3 & & & 41.3 & & & & 26.0 & & & 15.3 \\
\hline & $\mathrm{CN} 10 \mathrm{c}$ & $14 X-4-82$ & $\mathrm{G}$ & 0.7 & & & 18.7 & & & 41.0 & & & & 32.0 & & 0.3 & 7.0 \\
\hline & & $14 \mathrm{X}-\mathrm{CC}$ & $\mathrm{M}$ & & & & 21.3 & & & 34.7 & & & & 36.3 & & 0.3 & 7.3 \\
\hline Pliocene & & $15 X-1-5$ & $\mathrm{G}$ & & & & 52.0 & & & 23.3 & & & & 13.7 & & 0.7 & 10.3 \\
\hline & & $15 X-2-5$ & G & & & & 30.3 & & & 30.3 & & & & 36.3 & & 1.0 & 2.0 \\
\hline & & $15 X-3-5$ & $\mathrm{M}$ & 0.7 & & & 43.3 & & & 12.0 & & & & 37.0 & & 0.3 & 3.3 \\
\hline & & $15 X-4-5$ & $\mathrm{P}$ & 0.7 & & & 35.5 & & & 26.9 & & & & 34.6 & & 1.0 & 1.3 \\
\hline & & $15 X-5-5$ & $\mathrm{G}$ & 0.3 & & & 25.1 & & & 24.4 & & & 1.7 & 42.9 & & & 5.6 \\
\hline & & $15 \mathrm{X}-\mathrm{CC}$ & $M$ & & & & 29.7 & & & 21.0 & & & 0.7 & 42.7 & & & 6.0 \\
\hline & & $16 \mathrm{X}-1-34$ & $\mathrm{M}$ & & & & 6.7 & & & 19.7 & & & 1.7 & 22.0 & & 0.3 & 49.7 \\
\hline & & $16 \mathrm{X}-2-34$ & $\mathrm{G}$ & & & 0.3 & 18.3 & & & 18.0 & & & 2.0 & 20.0 & & & 41.3 \\
\hline & CNIOb & $16 X-3-34$ & $\mathrm{M}$ & & & & 9.3 & & 0.7 & 14.3 & & & 2.3 & 20.7 & & & 52.7 \\
\hline & & $16 \mathrm{X}-\mathrm{CC}$ & $\mathrm{P}$ & & & & 9.0 & & 0.7 & 15.3 & & & 4.7 & 8.6 & & & 61.8 \\
\hline & & $17 X-1-91$ & $\mathrm{P}$ & & & 0.3 & 3.7 & & 2.0 & 20.0 & & 16.0 & 1.0 & 13.0 & & 0.3 & 43.3 \\
\hline & & $17 X-2-91$ & $\mathrm{G}$ & & & & 1.7 & 0.3 & & 24.0 & & 30.7 & & 0.7 & & 1.7 & 39.7 \\
\hline & & $17 X-3-91$ & $\mathrm{M}$ & & 0.7 & & 4.3 & & 0.7 & 3.7 & & 6.0 & & 2.7 & & 0.3 & 81.7 \\
\hline & & $17 X-4-92$ & $\mathrm{G}$ & & 2.0 & & 5.7 & & 1.7 & 6.3 & & 30.7 & 1.7 & 2.0 & & 1.7 & 48.3 \\
\hline & & $17 X-5-91$ & $M$ & & 1.0 & & 5.0 & & 0.7 & 9.0 & & 16.3 & 1.3 & 1.3 & & 0.3 & 65.0 \\
\hline & & $17 \mathrm{X}-\mathrm{CC}$ & $\mathrm{M}$ & & 3.3 & & 5.7 & & 1.0 & 21.0 & & 21.0 & 0.7 & 1.0 & & 1.7 & 44.7 \\
\hline & & $18 X-1-28$ & G & & 1.3 & & 6.3 & & 1.3 & 12.3 & & 29.7 & 1.3 & 3.0 & & 1.3 & 43.3 \\
\hline & & $18 X-1-131$ & $\mathrm{G}$ & & 2.6 & & 2.6 & & 2.6 & 12.9 & & 16.6 & 1.3 & 1.7 & & 0.3 & 60.6 \\
\hline late & & $18 X-2-28$ & $M$ & & 1.0 & & 1.0 & & & 11.4 & & 35.2 & 1.0 & 1.0 & & & 45.7 \\
\hline Miocene & $\mathrm{CN} 9 \mathrm{~b}$ & $18 \mathrm{X}-\mathrm{CC}$ & G & & 2.0 & 0.3 & 3.3 & & & 16.9 & & 26.2 & 1.0 & 1.0 & & 1.0 & 47.7 \\
\hline & & $19 \mathrm{X}-1-35$ & $\mathrm{G}$ & & 2.0 & & 9.7 & & & 11.0 & & 6.7 & 2.0 & 2.3 & & 0.3 & 66.0 \\
\hline & & $19 X-3-47$ & $\mathrm{G}$ & & 12.0 & & 4.3 & & & 14.6 & & 14.0 & 0.7 & 3.0 & & 0.3 & 51.1 \\
\hline & & $19 \mathrm{X}-\mathrm{CC}$ & $\mathrm{P}$ & & 3.7 & & 7.6 & & 0.3 & 12.0 & & 15.9 & 1.0 & & & & 59.7 \\
\hline & & $20 X-1-37$ & $\mathrm{M}$ & & 4.3 & & 5.7 & & 1.7 & 10.7 & & 18.7 & 1.0 & 0.3 & & & 57.7 \\
\hline & & $20 \mathrm{X}-\mathrm{CC}$ & $\mathrm{M}$ & & 10.0 & & 21.0 & & 0.3 & 11.7 & & 24.3 & 1.7 & & & 0.3 & 30.7 \\
\hline & & $21 X-1-119$ & $\mathrm{M}$ & & & & 10.3 & & 0.7 & 4.3 & & 25.0 & & 6.7 & & & 41.3 \\
\hline & & $21 X-2-119$ & $\mathrm{M}$ & & 15.7 & 0.3 & 14.7 & & 1.7 & 10.3 & & 37.7 & & 0.7 & & 0.3 & 18.7 \\
\hline & & $21 X-3-119$ & $\mathrm{M}$ & & 10.3 & & 12.7 & & 1.0 & 32.3 & & 33,3 & & 1.7 & & & \\
\hline
\end{tabular}

"See list in Table 1 for identification of species. 


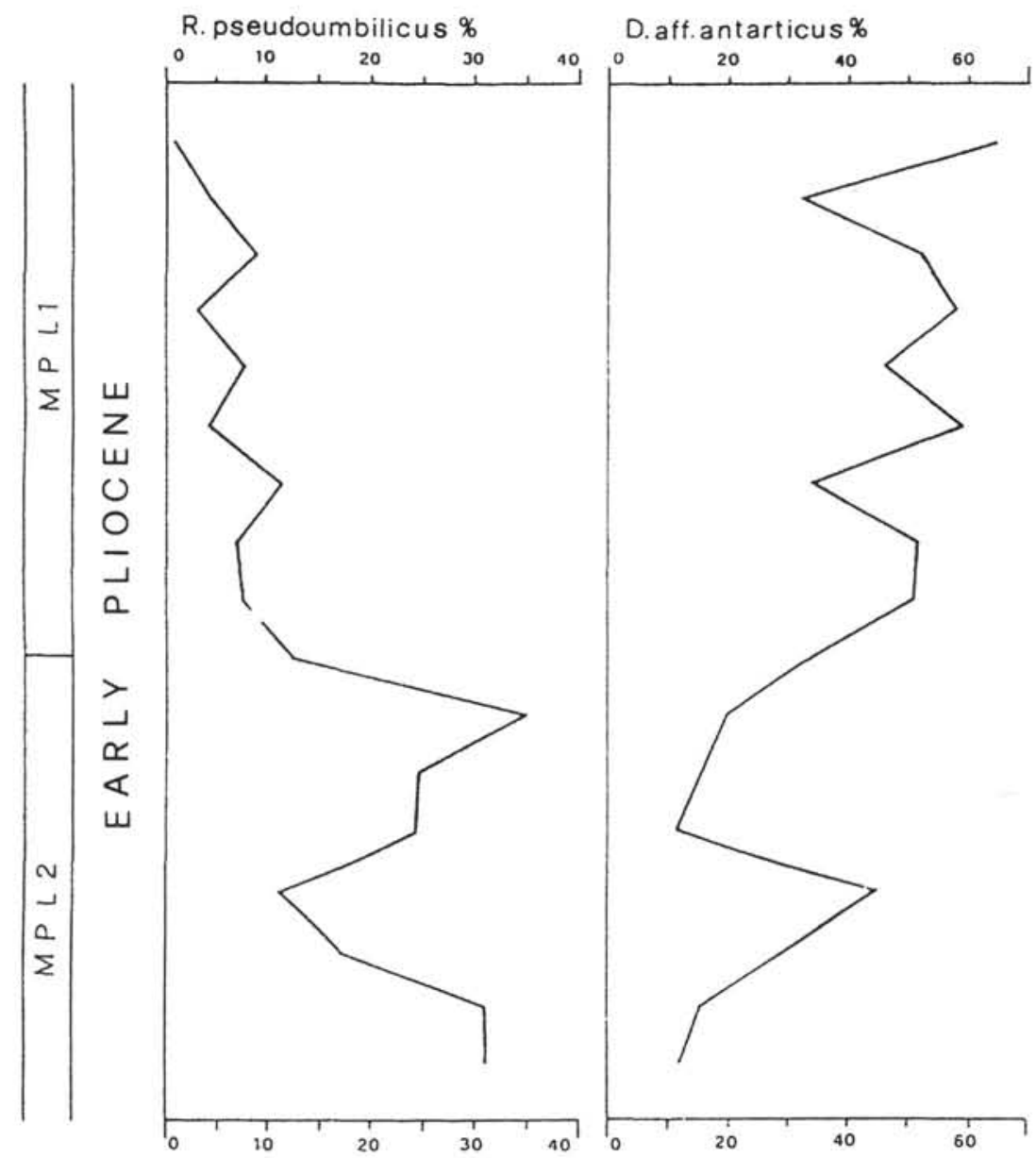

Figure 8. Percent of abundance of Reticulofenestra pseudoumbilicus and Dictyococcites aff. $D$. antarcticus, evaluated by counting at least 500 specimens from the early Pliocene section of Fiumara Capperano (Calabria, south Italy).

Bergen, J. A., 1984. Calcareous nannoplankton from Deep Sea Drilling Project Leg 78A: evidence for imbricate underthrusting at the lesser Antillian active margin. In Biju-Duval, B., Moore, J. C., et al., Init. Repts. DSDP, 78 (Pt. 1): Washington (U.S. Govt. Printing Office), 411-445.

Berggren, W. A., Kent, D. V., and Van Couvering, J. A., 1985. The Neogene: Part 2. Neogene geochronology and chronostratigraphy. In Snelling, N. J. (Ed.), The Chronology of the Geological Record. Geol. Soc. London Mem., 10:211-260.

Bukry, D., 1973. Low-latitude coccolith biostratigraphic zonation. In Edgar, N. T., Saunders, J. B., et al., Init. Repts. DSDP, 15: Washington (U.S. Govt. Printing Office), 685-703.

1975. Morphology and Phylogeny of the coccolithophycean family Ceratolithaceae. J. Res. U.S. Geol. Surv., 8:451-465.

Channell, J.E.T., Rio, D., Sprovieri, R., and Glaêon, G., 1990. Biomagnetostratigraphic correlations from Leg 107 in the Tyrrhenian Sea. In Kasten, K. A., Mascle, J., et al., Proc. ODP, Sci. Results, 107: College Station, TX (Ocean Drilling Program), 669-682.

Duncan, R. A., Backman, J., Peterson, L. C., et al., 1990. Proc. ODP, Sci. Results, 115: College Station, TX (Ocean Drilling Program).

Ellis, C. H., 1982. Calcareous nannoplankton biostratigraphy-Deep Sea Drilling Project Leg 60. In Hussong, D. M., Uyeda, S., et al., Init. Repts. DSDP, 60: Washington (U.S. Govt. Printing Office), 507-536.

Fryer, P., Pearce, J. A., Stokking, L. B., et al., 1990. Proc. ODP, Init. Repts, 125: College Station, TX (Ocean Drilling Program).

Gartner, S., 1977. Calcareous nannofossils biostratigraphy and revised zonation of the Pleistocene. Mar. Micropaleontol., 2:1-25.
Keigwin, L. D., Jr., and Shackleton, N. J., 1980. Uppermost Miocene carbon isotope stratigraphy of a piston core in the equatorial Pacific. Nature, 284:613-614.

Keller, G., Barron, J. A., and Burckle, L. H., 1982. North Pacific Late Miocene correlations using microfossils, stable isotopes, percent $\mathrm{CaCO}_{3}$, and magnetostratigraphy. Mar. Micropaleontol., 7:327-357.

Lohman, G. P., and Carlson, J. J., 1981. Oceanographic significance of Pacific late Miocene calcareous nannoplankton. Mar. Micropaleontol., 6:553-579.

Mazzei, R., Raffi, I., Rio, D., Hamilton, N., and Cita, M. B., 1979. Calibration of late Neogene calcareous plankton datum planes with the paleomagnetic record of Site 397 and correlation with Moroccan and Mediterranean sections. In von Rad, U., Ryan, W.B.F., et al., Init. Repts. DSDP, 47 (Pt.1): Washington (U.S. Govt. Printing Office), 375-389.

Müller, C., 1990. Nannoplankton biostratigraphy and paleoenvironmental interpretations from the Tyrrhenian Sea, ODP Leg 107 (Western Mediterranean). In Kastens, K. A., Mascle, J., et al., Proc. ODP, Sci. Results, 107: College Station, TX (Ocean Drilling Program), 495-511.

Okada, H., and Bukry, D., 1980. Supplementary modification and introduction of code numbers to the low-latitude coccolith biostratigraphic zonation (Bukry, 1973; 1975). Mar. Micropaleontol., 5:321-325.

Reid, F.M.H., 1980. Coccolithophorids of the North pacific Central Gyre with notes on their vertical and seasonal distribution. Micropaleontology, 26:151-176.

Rio, D., Raffi, I., and Villa, G., 1990. Pliocene-Pleistocene calcareous nannofossil distribution patterns in the western Mediterranean. In Kastens, 
Table 7. Percent distribution of discoaster species at Hole 786A, calculated after counting 300 specimens of the genus. ${ }^{a}$

\begin{tabular}{|c|c|c|c|c|c|c|c|c|c|c|c|c|c|c|c|}
\hline Age & Zones & Samples & $\mathrm{P}$ & 18 & 19 & 20 & 21 & 23 & 24 & 25 & 26 & 28 & 29 & 30 & 31 \\
\hline \multirow{12}{*}{$\begin{array}{c}\text { late } \\
\text { Pliocene }\end{array}$} & \multirow{12}{*}{$\mathrm{CN} 12 \mathrm{~A}$} & $1 \mathrm{H}-3-96$ & M & & & & 84.3 & & 13.7 & & & 0.3 & 0.3 & & 0.3 \\
\hline & & $1 \mathrm{H}-4-92$ & M & & & & 33.0 & & 58.7 & 0.3 & & 5.0 & 2.7 & & 0.3 \\
\hline & & $1 \mathrm{H}-5-52$ & G & 1.3 & & & 9.7 & & 79.7 & & & 6.7 & 2.3 & 0.3 & \\
\hline & & IH-6-120 & M & 5.3 & & & 28.0 & & 45.0 & & & 13.0 & 7.0 & 1.3 & 0.3 \\
\hline & & $1 \mathrm{H}-7-37$ & M & 2.3 & & & 24.0 & & 44.3 & 0.3 & & 19.0 & 6.7 & 0.7 & 2.7 \\
\hline & & $2 \mathrm{H}-1-52$ & G & 0.7 & & & 19.3 & & 66.7 & & & 5.0 & 7.3 & 0.3 & 0.7 \\
\hline & & $2 \mathrm{H}-2-31$ & M & 3.7 & & & 35.3 & & 40.7 & & & 12.0 & 8.3 & & \\
\hline & & $2 \mathrm{H}-3-81$ & M & 1.7 & & 0.3 & 22.6 & & 60.8 & & & 7.6 & 4.7 & 0.7 & 1.7 \\
\hline & & $2 \mathrm{H}-4-22$ & G & 1.0 & & & 21.3 & & 46.8 & & & 25.6 & 4.7 & & 0.7 \\
\hline & & $2 \mathrm{H}-5-59$ & G & 0.3 & & & 10.3 & & 70.7 & 0.3 & & 15.7 & 2.0 & 0.3 & 0.3 \\
\hline & & $2 \mathrm{H}-6-80$ & M & 6.0 & & & 39.7 & & 26.0 & & & 12.7 & 15.0 & 0.7 & \\
\hline & & $2 \mathrm{H}-\mathrm{CC}$ & G & 4.3 & & & 38.7 & & 26.3 & & & 22.0 & 6.0 & 1.0 & 1.7 \\
\hline \multirow{12}{*}{$\begin{array}{c}\text { early } \\
\text { Pliocene }\end{array}$} & \multirow{10}{*}{$\mathrm{CN} 10 \mathrm{c}$} & $3 \mathrm{H}-1-85$ & M & 2.3 & & & 38.0 & & 22.0 & & & 34.3 & & & 3.3 \\
\hline & & $3 \mathrm{H}-2-85$ & M & 0.3 & & 0.3 & 20.3 & & 31.7 & & & 45.0 & & & 2.3 \\
\hline & & $3 \mathrm{H}-3-85$ & G & 0.2 & & & 30.7 & & 29.7 & & & 30.7 & & 0.2 & 8.7 \\
\hline & & $3 \mathrm{H}-4-85$ & G & & & & 39.1 & & 26.5 & & & 29.5 & & 0.3 & 4.6 \\
\hline & & $3 \mathrm{H}-5-85$ & M & & & & 24.4 & & 17.1 & & & 42.1 & & 1.3 & 15.1 \\
\hline & & $3 \mathrm{H}-6-85$ & M & 0.3 & & & 39.7 & & 38.7 & & & 15.6 & & & 5.6 \\
\hline & & $3 \mathrm{H}-\mathrm{CC}$ & G & & & & 18.0 & & 53.7 & & & 24.3 & & 0.3 & 3.7 \\
\hline & & $4 X-1-97$ & M & 0.3 & & & 43.7 & 0.3 & 15.0 & & & 38.7 & & 0.3 & 1.7 \\
\hline & & $4 X-2-13$ & M & & & & 39.4 & & 25.3 & & & 29.4 & & 1.0 & 4.0 \\
\hline & & $4 \mathrm{X}-\mathrm{CC}$ & M & 0.3 & & 0.3 & 36.4 & & 22.8 & & & 38.1 & & 0.7 & 1.3 \\
\hline & \multirow[b]{2}{*}{$\mathrm{CN} 9 \mathrm{~b}$} & $5 X-1-132$ & G & & 13.3 & 0.3 & 8.3 & 2.0 & 3.3 & & 31.9 & 0.3 & & & 40.5 \\
\hline & & $5 X-2-26$ & $\mathrm{P}$ & & 10.0 & 0.3 & 17.0 & 1.0 & 5.7 & & 28.0 & 4.3 & & 0.3 & 33.3 \\
\hline
\end{tabular}

${ }^{\text {a }}$ See list in Table 1 for identification of species.

Table 8. Percent distribution of discoaster species at Hole 781A, calculated after counting 300 specimens of the genus. ${ }^{a}$

\begin{tabular}{|c|c|c|c|c|c|c|c|c|c|c|c|c|}
\hline Age & Zones & Samples & $\mathrm{P}$ & 18 & 20 & 21 & 24 & 25 & 28 & 29 & 30 & 31 \\
\hline \multirow{9}{*}{ Pliocene } & \multirow{8}{*}{$\mathrm{CN} 12 \mathrm{a}$} & $15 \mathrm{R}-\mathrm{CC}$ & M & & & 65.3 & 28.7 & \multirow{9}{*}{0.7} & 4.0 & & 0.7 & 1.3 \\
\hline & & $16 \mathrm{R}-\mathrm{CC}$ & M & & & 77.0 & 20.0 & & 1.3 & 1.3 & & 0.3 \\
\hline & & 18R-CC & M & & 0.7 & 25.7 & 53.7 & & 18.7 & 0.7 & 0.7 & \\
\hline & & $21 \mathrm{R}-1-4$ & M & 0.3 & 0.3 & 18.2 & 42.9 & & 36.6 & 1.0 & & 0.7 \\
\hline & & 2IR-CC & M & & 0.3 & 16.3 & 41.3 & & 41.3 & & & 0.7 \\
\hline & & 22R-CC & M & & 0.7 & 14.7 & 61.3 & & 22.3 & 1.0 & & \\
\hline & & 23R-CC & G & 0.7 & & 15.0 & 56.0 & & 26.3 & 1.0 & 0.7 & 0.3 \\
\hline & & 23R-CC & M & 1.7 & & 15.0 & 66.3 & & 12.0 & 2.7 & 1.3 & 0.3 \\
\hline & CNIIb & $26 R-1-17$ & G & 1.3 & 0.3 & 11.3 & 40.7 & & 35.0 & 1.3 & 1.3 & 8.7 \\
\hline
\end{tabular}

"See list in Table 1 for identification of species.

K. A., Mascle, J., et al., Proc. ODP, Sci. Results, 107: College Station, TX (Ocean Drilling Program), 513-533.

Shackleton, N. J., and Kennett J. P., 1975. Paleotemperature history of the Cenozoic and the initiation of Antarctic glaciation: oxygen and carbon isotope analyses in DSDP Sites 277, 279 and 281. In Kennett, J. P., Houtz, R. E., et al., Init. Repts. DSDP, 29: Washington (U.S. Govt. Printing Office), 743-755.

Thierstein, H. R., Geitzenauer, K. R., and Molfino, B., 1977. Global synchroneity of late Quaternary coccolith datum levels: validation by oxygen isotopes. Geology, 5:400-404.
Thierstein, H. R., and Opdyke N. D., 1977. Oxygen isotope and paleomagnetic evidence for early Northern Hemisphere glaciation. Nature, 270:216-219.

Thunell, R. C., 1979. Pliocene-Pleistocene paleotemperature and paleosalinity history of the Mediterranean Sea. Results from DSDP Sites 125 and 132. Mar: Micropaleontol., 4:173-187.

Date of initial receipt: 20 October 1990 Date of acceptance: 6 May 1991 Ms 125B-141 


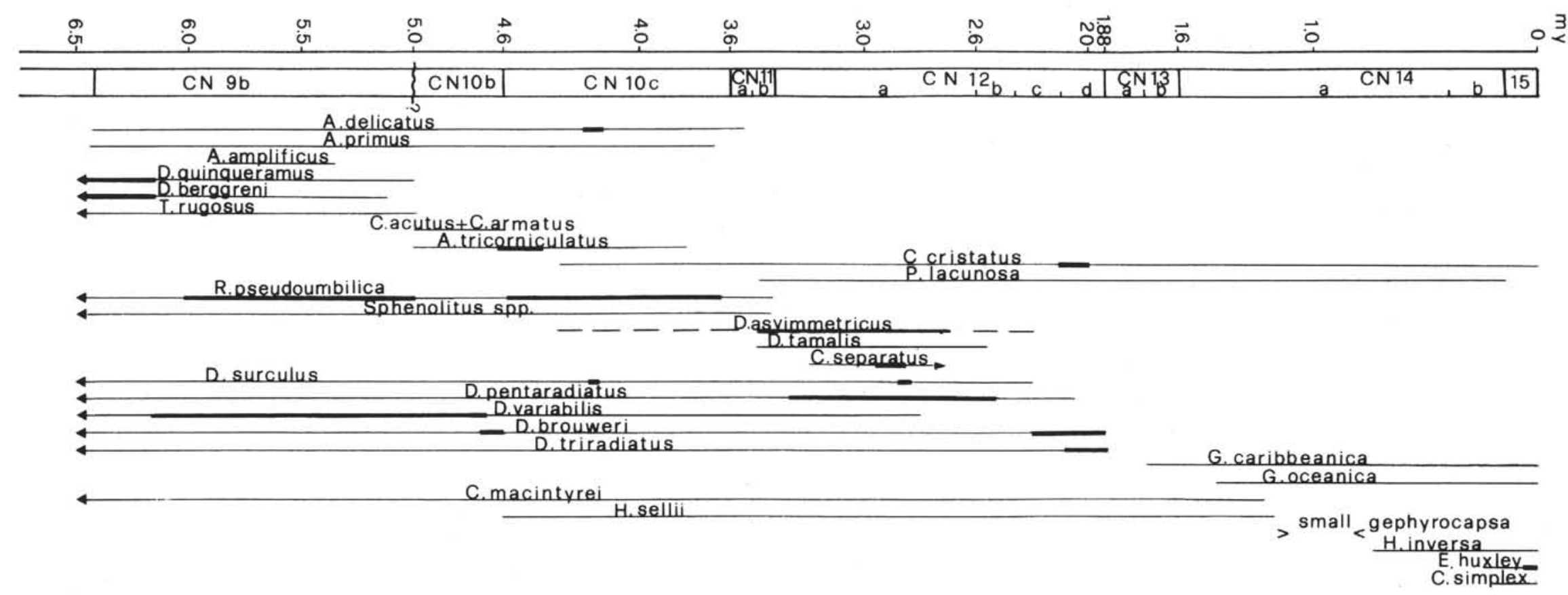

Figure 9. Distribution of selected calcareous nannofossils from Leg 125. The heavy lines represent the acme in abundance. 


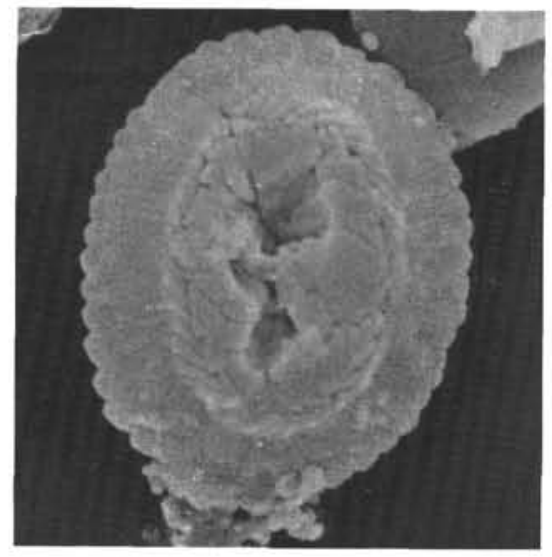

1

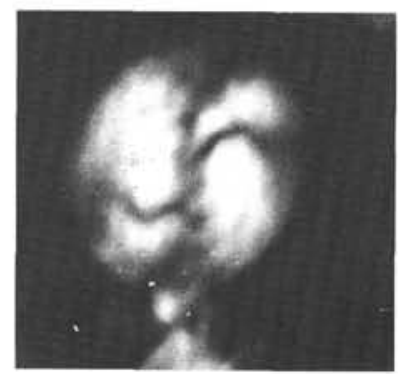

2

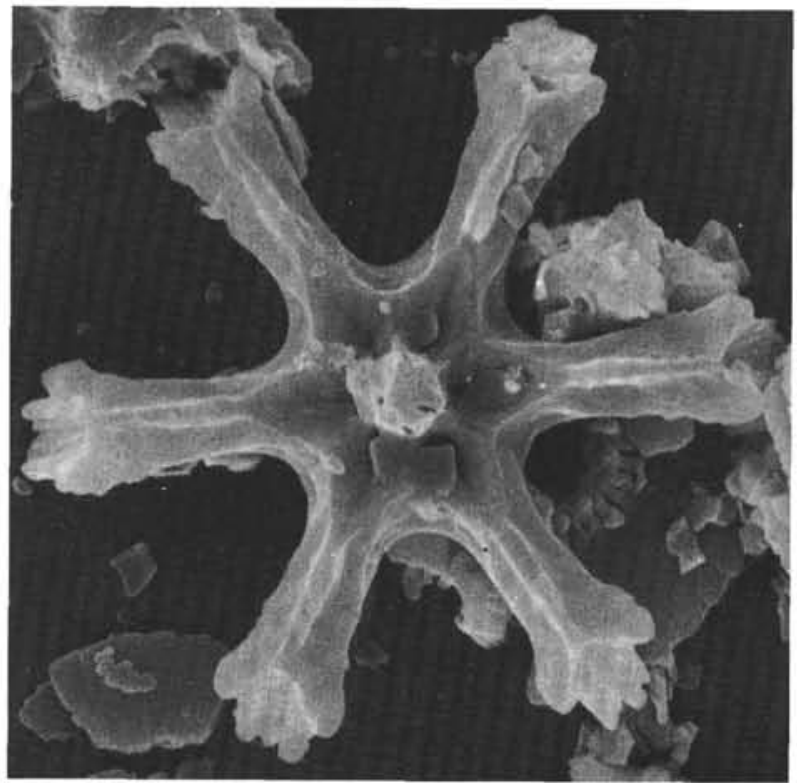

4

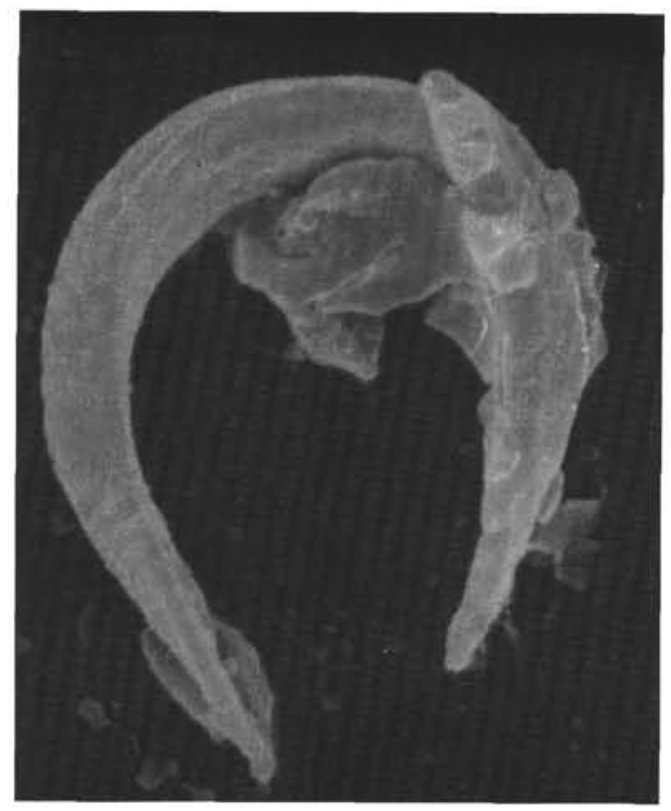

3

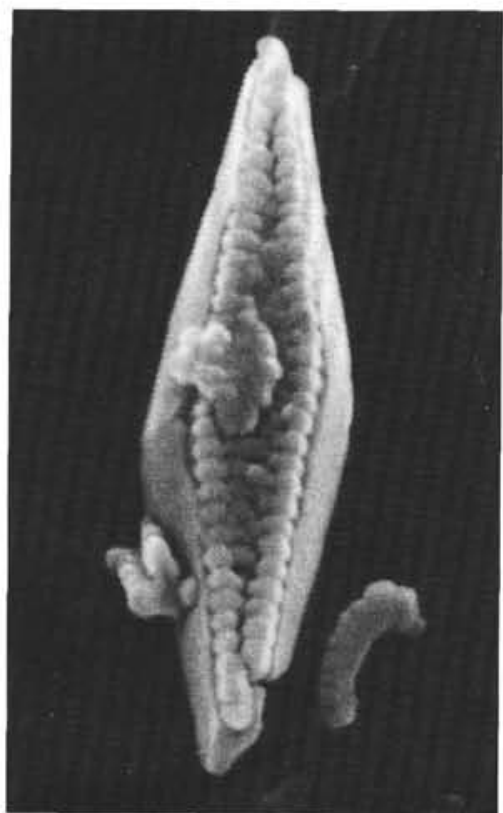

5

Plate 1. 1-2. Dictyococcites aff. D. antarcticus Haq (1976); 1. Sample 125-782A-18X-2, 28-29 cm. $\times 10,000.2$. Cross-polarized light, Sample 125-782A-16X-3, 34-35 cm. $\times 3800$. 3. Amaurolithus delicatus Gartner and Bukry (1975). Sample 125-782A-18X-2, $28-29 \mathrm{~cm} . \times 8750.4$. Discoaster surculus Martini and Bramlette (1963). Sample 125-786A-3H-CC $\times 5000$. 5. Scapholithus fossilis Deflandre (1954). Sample 125-782A-1H-1, 11-12 cm. ×13,000. 


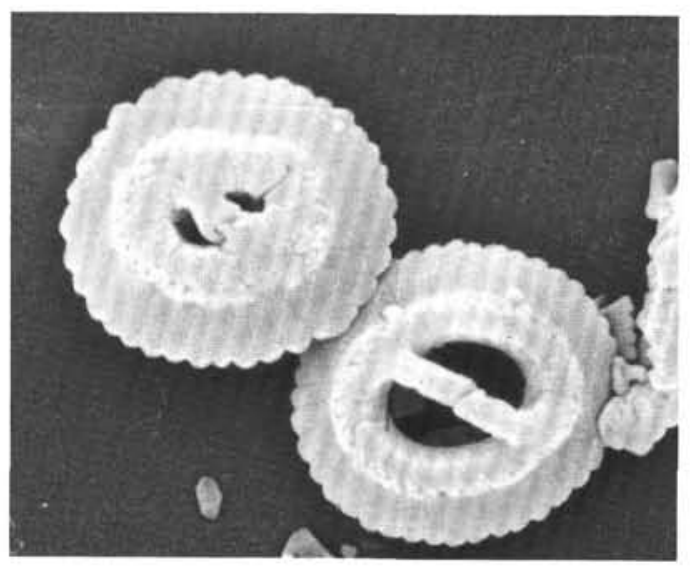

1

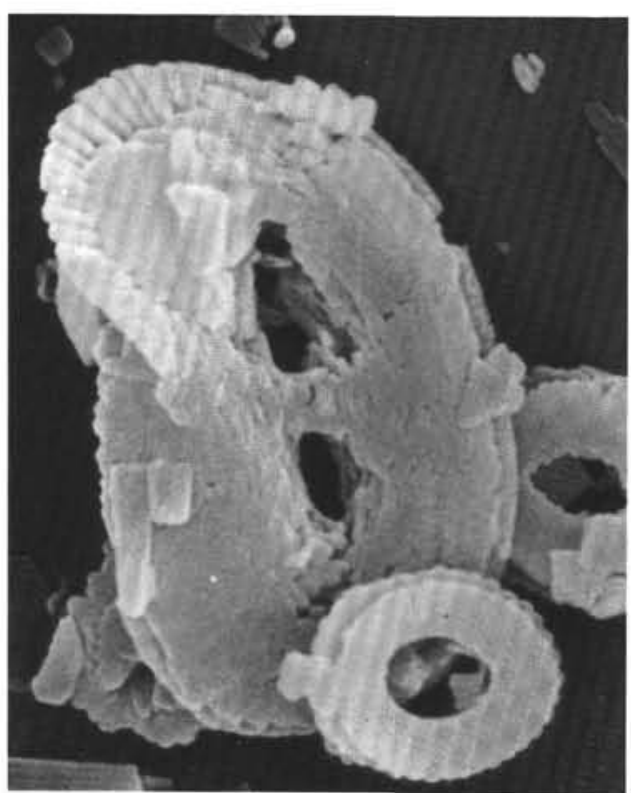

3

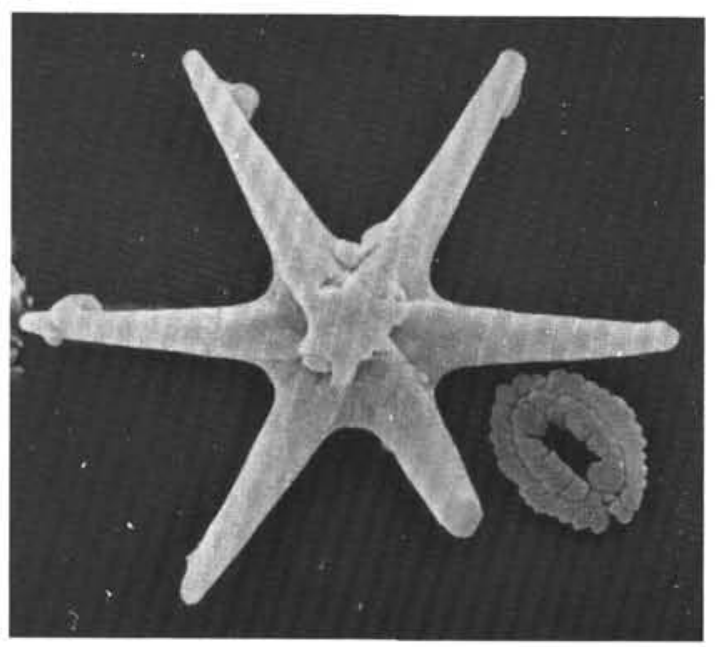

5

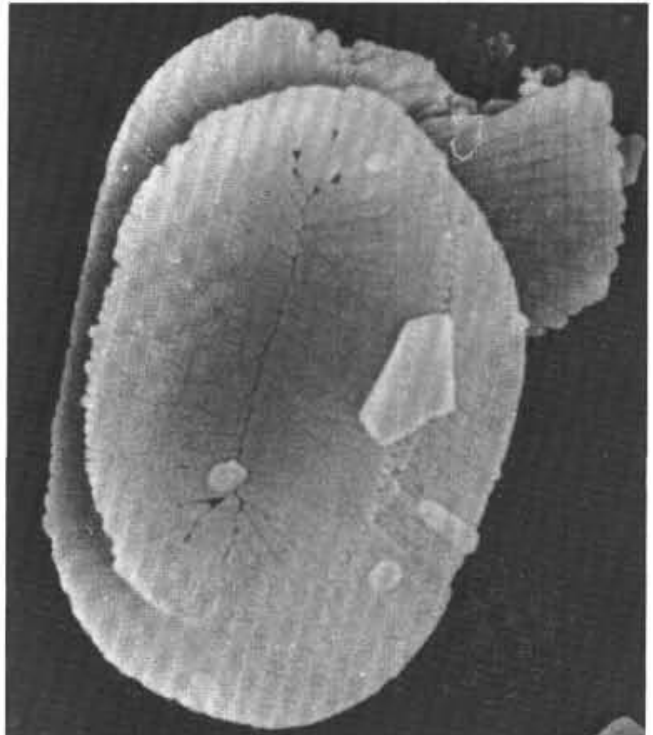

2
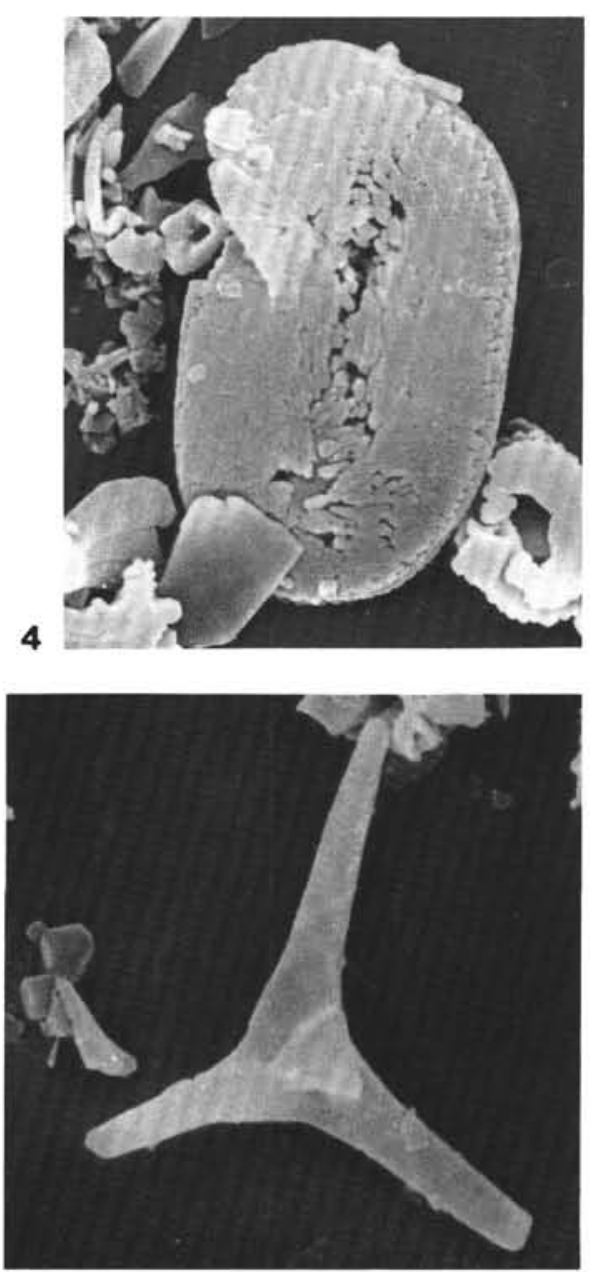

6

Plate 2. 1. Gephyrocapsa caribbeanica Boudreaux and Hay (1969) left, Gephyrocapsa oceanica Kamptner (1943) right. Sample 125-785A-1H-1, $145-146 \mathrm{~cm} . \times 10,000$. 2. Helicosphaera hyalina Gardner (1970). Sample 125-785A-1H-1, 145-146 cm. $\times 8750.3$. Helicosphaera inversa Gartner (1980). Sample 125-785A-1H-1, 145-146 cm. $\times 8750$. 4. Helicosphaera neogranulata Gartner (1927). Sample 125-785A-1H-1, 145-146 cm. $\times 6500$. 5. Discoaster brouweri Tan (1927) emend. Bramlette and Riedel (1954). Sample 125-782A-18X-2, 28-29 cm. $\times 8000$. 6. Discoaster triradiatus Tan (1927). Sample 125-782A-18X-2, 28-29 cm. $\times 5000$. 